Article

\title{
Environmental Threats over Amazonian Indigenous Lands
}

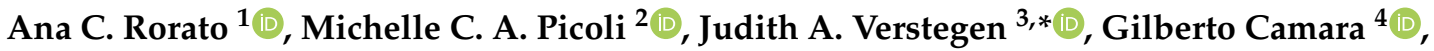 \\ Francisco Gilney Silva Bezerra ${ }^{1}$ (D) and Maria Isabel S. Escada ${ }^{2}$ (D) \\ 1 Earth System Science Center, National Institute for Space Research (INPE), \\ São José dos Campos 12227-010, Brazil; ana.rorato@inpe.br (A.C.R.); francisco.gilney@inpe.br (F.G.S.B.) \\ 2 National Institute for Space Research (INPE), General Coordination of Earth Sciences (CGCT), \\ São José dos Campos 12227-010, Brazil; michelle.picoli@inpe.br (M.C.A.P.); isabel.escada@inpe.br (M.I.S.E.) \\ 3 Laboratory of Geo-Information Science and Remote Sensing, Wageningen University, \\ 6708 PB Wageningen, The Netherlands \\ 4 Group on Earth Observations (GEO), CH-1211 Geneva, Switzerland; gcamara@geosec.org \\ * Correspondence: judith.verstegen@wur.nl
}

Citation: Rorato, A.C.; Picoli, M.C.A.; Verstegen, J.A.; Camara, G.; Silva Bezerra, F.G.; S. Escada, M.I. Environmental Threats over Amazonian Indigenous Lands. Land 2021, 10, 267. https://doi.org/ 10.3390/land10030267

Academic Editors: Cynthia Simmons and Robert T. Walker

Received: 1 February 2021

Accepted: 4 March 2021

Published: 6 March 2021

Publisher's Note: MDPI stays neutral with regard to jurisdictional claims in published maps and institutional affiliations.

Copyright: (c) 2021 by the authors. Licensee MDPI, Basel, Switzerland. This article is an open access article distributed under the terms and conditions of the Creative Commons Attribution (CC BY) license (https:/ / creativecommons.org/licenses/by/ $4.0 /)$.

\begin{abstract}
This study investigates the main threats related to environmental degradation that affect Amazonian Indigenous Lands (ILs). Through a cluster analysis, we group ILs according to the set of common environmental threats that occur within and outside their limits. The results show that most of the 383 ILs are affected internally by a combination of different environmental threats, namely: deforestation, forest degradation, fires, mining, croplands, pastures, and roads. However, the ILs affected by multiple and relatively severe threats are mainly located in the arc of deforestation and the Roraima state. The threats related to forest loss (deforestation, forest degradation, and fires) are more intense in the ILs' buffer zones than within, showing that ILs effectively promote environmental preservation. In the cluster analysis, we identified seven clusters that are characterized by common environmental threats within and around their limits, and, based on these results, we have outlined four environmental policy priorities to be strengthened and applied in Amazonian ILs: protecting ILs' buffer zones; strengthening surveillance actions, and combating illegal deforestation, forest degradation, and mining activities in ILs; preventing and fighting fires; and removing invaders from all ILs in the Amazon. In this study, we warn that the threats presented make the Indigenous peoples in the Amazon more vulnerable. To guarantee indigenous peoples' rights, illegal actions in these territories and their surroundings must be contained, and quickly.
\end{abstract}

Keywords: Indigenous rights; Indigenous lands; environmental degradation; policy; Amazon; cluster analysis

\section{Introduction}

According to Brazil's Federal Constitution, Indigenous Lands (ILs) are territories demarcated to guarantee Indigenous peoples the right to their lands, their livelihood, and their social organization [1]. Under Brazil's law, the Indigenous peoples have the original right to exclusive use of the lands they traditionally occupy [1-3]. The Brazilian Legal Amazon region (the so-called Brazilian Legal Amazon (BLA) is a political-administrative region covering approximately 5 million $\mathrm{km}^{2}$. The BLA comprises the states of Acre (AC), Amapá (AP), Amazonas (AM), Pará (PA), Rondônia (RO), Roraima (RR), Mato Grosso (MT), Tocantins (TO), and part of Maranhão (MA) [4]) shelters the world's largest concentration of Indigenous peoples, divided into several ethnic groups and holding a rich socio-cultural diversity. In this region, approximately 355,000 Indigenous people, divided into 155 ethnic groups, inhabit 383 Indigenous Lands [1,5].

The ILs in Brazil are crucial areas for preserving human ethnocultural heritage. Furthermore, they provide myriad ecosystem services, such as regulating the climate and the hydrological cycle [6-9]. Given that the ILs cover more than 1,160,000 $\mathrm{km}^{2}$, representing $22 \%$ of the BLA [1], they are crucial for preserving biodiversity. In Brazil, more than half 
of all ILs retain 90\% of pristine vegetation [9]. Further, Amazonian ILs are considered the most important obstacle to deforestation [10,11] and have been shown to contribute far more to reducing emissions from deforestation and forest degradation (REDD) than parks or nature reserves because they cover three times the area and are often in the immediate path of the expanding agricultural frontier [12].

The Amazon region is currently affected by multiple environmental threats [10,13-17], defined here as degrading processes or activities that reduce the environmental integrity of a given area. Among the most important environmental threats to the Amazon are deforestation, logging, fires [18,19], illegal land grabbing, large infrastructure projects (such as hydroelectric plants and long highways) [20], mineral exploitation [21-23], and the expansion of the agricultural frontier [24-26].

These threats result from an intricate network of social and economic factors that interact with each other. For example, the profitability of the land market encourages people to convert the land to supply the national and international demand for commodities $[25,27,28]$. Regarding deforestation, important drivers of this problem in the Amazon are large-scale mechanized agriculture and extensive livestock farming. Furthermore, the economic gains from mining and logging further increase deforestation and forest degradation. By 2019, the Brazilian Amazon reached about 20\% forest loss [18].

In general, these environmental threats to the Amazonian ecosystem result in loss of forest, loss of habitat for biodiversity, soil erosion, pollution of rivers, and increased susceptibility to fire. Within the ILs, these environmental threats affect people's livelihoods and welfare directly and indirectly, e.g., increasing forest fragmentation, reducing hunting and gathering availability, and drying and polluting rivers [14,16,29]. These threats also put the territorial integrity of ILs and Indigenous peoples' safety at risk, as the invasion of ILs can result in land conflicts between Indigenous peoples and the invaders $[14,15,30]$. Furthermore, illegal occupation and forced contact with external non-Indigenous peoples are often responsible for the spread of diseases in which Indigenous peoples have no immunity [16]. The environmental threats in the ILs' surroundings also have the potential to affect ILs' environmental integrity (e.g., fire spreading) and people's health and welfare (e.g., contamination by mining pollutants arising from nearby mining activities) [30,31]. In Brazil, the law establishes buffer zones around conservation units (UCs) to protect them against threats, but this regulation does not apply to Indigenous Lands.

In recent years, Brazil has undergone major institutional and environmental policy changes $[32,33]$. The country is under the command of a government that defends the wide economic exploitation of the Amazon, including opening ILs for extractive activities $[22,34]$. Additionally, a systematic dismantling of environmental policies has been implemented in recent years, reflecting in the suppression and weakening of territorial and environmental surveillance agencies $[32,33,35,36]$. For example, in recent years the action of the National Indigenous Foundation (FUNAI), the Brazilian agency responsible for implementing the policy to promote and guarantee Indigenous rights, has been undermined and weakened $[32,37,38]$.

With reduced protection, several ILs in the Amazon have been encroached upon by illegal loggers, farmers, squatters, and gold miners, increasing Indigenous peoples' vulnerability [30,31,37]. According to the report of the Indigenous Missionary Council [31], between 2018 and 2019 there was a 134\% increase in cases of possessory invasions, illegal exploitation of resources, and damage to property in ILs. In 2018, 109 of these cases were registered in 76 ILs distributed across 13 Brazilian states, while in 2019, 256 cases were registered in 151 ILs across 23 states. In 2019, 277 cases of violence were recorded against Indigenous people in Brazil (113 of which were murders), more than double the 110 cases recorded in 2018 [31]. The reduced surveillance and the government's favorable bent toward liberating economic activities in the ILs has been encouraging the invaders and giving them a sense of impunity. In addition, the rise in the value of gold [39] and the depletion of wood economically valuable outside the ILs are also responsible for boosting illegal mining and logging in these territories [9]. 
In general, most studies carried out for Amazon Indigenous Lands have evaluated these areas combined with other types of protected areas (PAs). Some of these studies have focused on whether different types of PAs have different capacities for avoiding the advancement of deforestation into their boundaries, using the relation between deforestation [10,40,41] or forest fragmentation [42] inside and outside these areas. In another approach, other studies have investigated the carbon stocks in Amazonian PAs, also including ILs [6,43]. For example, Nogueira et al. [43] estimated the loss of carbon stocks in these areas, while Walker et al. [6] performed a risk assessment of the carbon stocks by mapping the distribution of multiple current and potential risk factors, e.g., agriculture, grazing, mining, petroleum extraction, timber supply, and transportation. In a recent attempt to investigate the vulnerability of PAs in Brazil to climate change, Lapola et al. [44] developed indicators of climatic-change hazard and PA resilience (size, native vegetation cover, and the probability of climate-driven vegetation transition). They found that over $80 \%$ of Brazil's PAs of high or moderate vulnerability to future climate change are ILs. Despite the important contribution of these studies, the current situation of Amazonian ILs is still murky, as is the complex arrangement of multiple threats that are causing environmental degradation in these areas. In addition, studies are needed to assess the impacts of the recent weakening of environmental legislation with regard to the protection of these territories.

Amazonian Indigenous Lands are widely distributed by regions with different contexts of occupation and environmental degradation. As such, these territories present different environmental impacts within and outside of their limits. While some ILs are located in very deforested regions and with high permeability due to the dense access by highways, other ILs are located in more preserved regions with dense forest cover around them and with less accessibility. Likewise, some ILs have a predominance of different threats, some being more affected by illegal mining, others by logging, and others by the heavy occupation of farmers [31]. For the development of appropriate public policies aimed at mitigating environmental impacts on ILs, it is necessary to understand how internal and external threats are distributed over the ILs. Identifying groups of ILs with a common set and severity of threats can lead to the design of policy pathways dedicated to each of these groups.

This study aims to help fill this gap by presenting the first investigation on the main threats (introduced in the next section) involved in environmental degradation of Amazonian ILs. Here we intend to answer the following questions: (i) Which groups of Amazonian Indigenous Lands with a common set of internal and external environmental threats can be identified? (ii) To what extent do the environmental threats inside and around Indigenous Lands differ? To do this, we use cluster analysis to group the ILs according to the set of common environmental threats inside and outside their limits (i.e., deforestation, forest degradation, fire, mining, croplands, pastures, and roads). Hereby, we highlight the homogeneity and heterogeneity of the processes responsible for the environmental impacts in ILs and their surroundings. Finally, we discuss the potential public policy strategies for mitigating environmental threats for each IL cluster.

\section{Environmental Threats and Their Impacts on Amazonian Indigenous Lands}

\subsection{Deforestation}

Deforestation configures a key environmental threat in the Amazon region, being the most important driver of shifting ecosystem functioning, composition, and balance [45,46]. In general, deforestation leads to the destruction of habitats and depletion of species, causes soil erosion, reduces soil fertility, and leads to silting of water bodies and the drying of the river springs. As consequences of deforestation, Indigenous peoples also face decreased natural resources for subsistence, such as animals, fish, fruits, trees used for construction, and medicinal herbs. In the last years, a significant increase in deforestation rates has been observed in Indigenous Lands [18,30,31]. According to the Amazon Deforestation 
Monitoring Program (PRODES) from INPE, an area of $888.5 \mathrm{~km}^{2}$ was deforested inside ILs between 2017 and 2019, representing a 117\% increase between the two years [18].

\subsection{Forest Degradation}

Unlike deforestation, which is the result of rapid forest clear-cutting, forest degradation is characterized by the gradual and long-term process of reducing forest cover as the result of selective logging and fires $[47,48]$. Forest degradation alters the forest structure, ecological composition, and the local climate. Illegal logging has been a major cause of forest degradation within Amazonian ILs and of violent conflicts between Indigenous peoples and loggers [15]. In addition, logged forests are strictly associated with higher fire risks, as microclimatic changes make the forest drier [49].

\subsection{Fires}

In the Amazon, fires are the result of different drivers [49]. To prevent forest fires in Indigenous Lands, it is important to differentiate between uncontrolled fire provoked by natural, accidental, or criminal causes and controlled burning practices (i.e., controlling fire intensity and limiting it to an area). Indigenous peoples in Brazil use controlled fire in different circumstances, such as hunting, fertilizing the soil with ashes, opening and preparing the land for planting, and removing venomous animals. This practice is most intensive in Amazonian ILs with predominantly savanna vegetation [49,50]. Among the several consequences of uncontrolled forest fires are the loss of forest cover and biodiversity, respiratory diseases, imbalance of the local ecosystem, economic loss [13,51,52], and the loss of Indigenous villages [50]. Between January and August 2019, there was an 88\% increase in fires in Brazil's Indigenous Lands compared to the same period in 2018 [19]. In 2020, the fires in these territories worsened in relation to 2019 [19] and were mainly due to criminal fires or the spread of fires initiated in the ILs' surroundings [50]. In 2020, several Indigenous peoples mobilized to fight the fires in their territories, but they lacked government support $[53,54]$.

\subsection{Agricultural and Livestock Expansion}

The expansion of the agricultural and livestock frontier over tropical forests represents a central environmental issue due to its negative impacts on water availability, soil quality, biodiversity, and local climate $[25,55,56]$. The advancement of crop and livestock areas over Indigenous Lands threaten the environmental integrity by increasing access to the ILs, increasing the forest's exposure to fire due to agricultural practices, and, in the case of largescale agriculture, the use of pesticides can cause water contamination [9,31]. Furthermore, land tenure disputes between Indigenous peoples and farmers have historically been marked by situations of intense conflict and violence [15,30]. Several ILs in the Amazon are immersed in a matrix of agricultural or pasture lands, where the boundary of the IL is often the boundary between forest and monoculture cropland; besides the risk for disputes, this has consequences for the biodiversity in the IL due to the 'edge effect' [57].

\subsection{Road Access}

Until the 1950s, Brazilian Amazon occupation was limited to the coastal region and the banks of the main rivers, such that relatively few changes were made in the forest cover at the regional scale [58]. Nowadays, road access is the primary determinant of the spatial distribution of deforestation $[20,26,59,60]$. That is, forests have been logged, deforested, and converted to other uses mainly where roads provide easy access [20]. In this way, the road network plays an important role in shaping the patterns of environmental degradation in the Amazon [13,59,61]; therefore, ILs closer to regions with a dense road network tend to be more exposed to environmental threats. 


\subsection{Mining}

Lastly, mining causes intense socio-environmental impacts in the Amazon region [62,63]. This activity is related to several environmental perturbations, such as contaminating watercourses, soil, and wildlife, and driving deforestation $[9,14,15,21,62,63]$. In addition, mining is related to severe social impacts, such as contamination by toxic chemical residue [64] and violent situations [65-67]. Historically, mining is the precursor to other activities, such that it enables access to other agents and activities such as logging, land market, cattle raising, and even the establishment of larger mining companies, implying more deforestation [68,69]. The encroachment of illegal mining in Indigenous territories has been increasing in the last three years [30,70]. According to Rorato et al. [22] 551 deforested areas classified as mining were detected in 13 Amazonian ILs between 2017 and 2019, totaling $57.8 \mathrm{~km}^{2}$.

\section{Materials and Methods}

\subsection{Overview}

In this study, we identified the main environmental threats to ILs (i.e., deforestation, forest degradation, fire, mining, croplands, pastures, and road access) and developed a set of indicators to represent them. Based on these indicators, and using cluster analysis, we identified and characterized different clusters of ILs with a set of common environmental threats inside and outside their limits. Finally, we discussed the application of existing environmental policies to combat the advancement of these threats over the Amazonian ILs and how they can be prioritized according to the clusters found. In the next sections, we present the study area [Section 3.2], the environmental threat indicators [Section 3.3], and the cluster analysis [Section 3.4].

\subsection{Study Area}

We analyzed 383 Indigenous Lands fully located in the Legal Amazon region (Figure 1) for all legal status (the legal status refers to the recognition status of the Indigenous peoples' rights to land by the State. In the Legal Amazon region 325 ILs are Regularized while the rest are in one of the following recognition stages: In Study (6), Delimited (11), Declared (31), Indigenous reserve forwarded (7), and Homologated (3) [1,71] (Table A1 in the Appendix A)), as they are subject to the same environmental and land policies. The boundaries for all ILs in the Legal Amazon were obtained from the FUNAI website [72].

Both the Federal Constitution and the Statute of the Indian (Law 6.001/73) guarantee Indigenous people's permanent possession of the lands they live on, recognizing their right to exclusive usufruct of the natural wealth and all the uses of these existing lands [2,3]. Any form of land lease or any legal act or business that restricts direct ownership by Indigenous peoples is prohibited on ILs. Further, non-Indigenous people are prohibited from hunting, fishing, settling, or developing agricultural or extractive activities in these territories [3].

\subsection{Environmental Threat Indicators and Data}

To explore the environmental integrity of Amazonian ILs, we built a spatial database combining the set of environmental threats described in Section 2. Indicators of environmental threat were calculated using maps and data of deforestation, forest degradation, land use, fire, roads, and mining, inside and around the ILs. We considered the boundaries of ILs (inside) and a buffer area of $10 \mathrm{~km}$ around each IL (outside). This buffer zone is based on the literature $[10,11,42]$ and on environmental rules. Different environmental policies in Brazil have established a 10-km-radius surrounding protected areas to save its ecosystems against all activities that may affect the biota, such as the repealed CONAMA (National Environmental Council) Environmental Resolution no. 13/1990, the Decree 99.274/1990, and the Interministerial Ordinance No. 60 of 2015, in the case of mining exploitation and railway construction [73]. The indicators we used to represent the environmental threats considered in this study are described below and summarized in Table 1. 


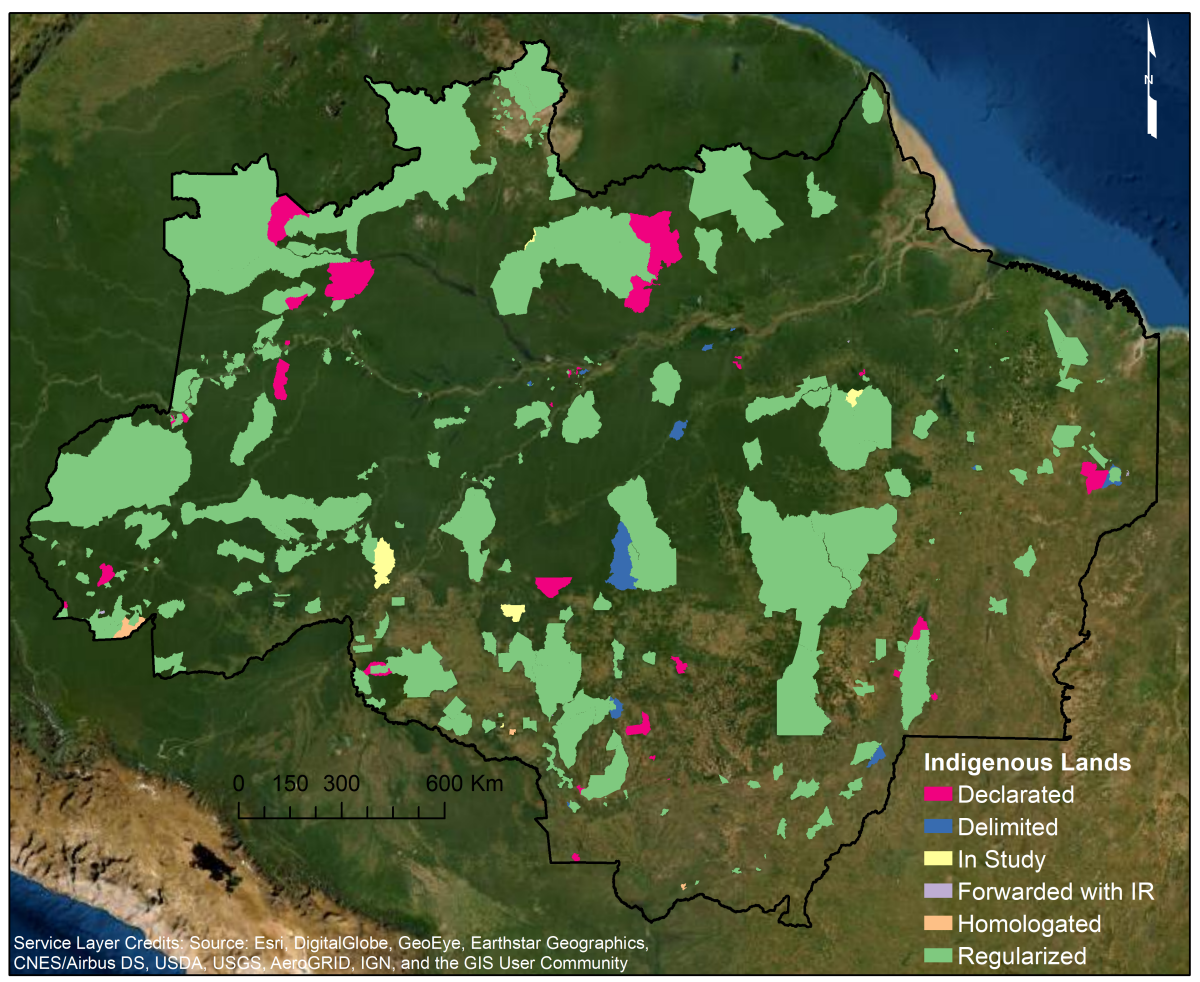

Figure 1. Indigenous Lands in the Legal Amazon region. The Legal Amazon region is delimited by the black line. Colors indicate the legal status of recognition process. Data source: FUNAI (2020).

Deforestation was expressed as the accumulated percentage of deforested area relative to the IL area or buffer zone (BF) area. Hereto, we used the accumulated deforestation data through 2019 from INPE's Amazon Deforestation Monitoring Program (PRODES) [18]. The PRODES has carried out satellite monitoring of clear-cutting (complete suppression of the forest) in areas of forest physiognomy in the Legal Amazon since 1988.

Forest degradation was expressed as the accumulated percentage of the area of degraded forests relative to the IL or BF areas. Data were obtained from DEGRAD, an INPE system to detect progressive forest degradation [48] between 2007 and 2016. Although the DEGRAD system was discontinued in 2016, the detection of forest degradation is currently provided by the Real-time Deforestation Detection System (DETER) [70], a system to detect forest perturbations also developed by INPE $[47,70]$. Data provided by both DEGRAD (2007-2016) and DETER (2016-2019) were combined to generate the forest degradation indicator from 2007 until 2019. In this study, we adopt the definition of forest degradation used by INPE: the process of the gradual loss of forest cover due to the effect of logging and forest fire, of at least 6.25 ha, which does not qualify as clear-cut deforestation by PRODES [48]. We discounted the overlap of areas that have suffered forest degradation more than once.

As an indicator for fires, we computed the accumulated percentage of burned area relative to the IL or BF area. Hereto, data from MODIS' (NASA's Moderate Resolution Imaging Spectroradiometer) Global Burned Area Product (Collection 6) between 2001 and 2019 was used [74]. The MODIS burned area mapping algorithm detects burned areas daily by locating the occurrence of rapid changes in surface reflectance patterns at a spatial resolution of $500 \mathrm{~m}$. Burned areas are characterized by vegetation loss, accumulation of coal and ash, and changes in the vegetation structure. Based on these characteristics, the burned areas are classified. In this indicator, we also discounted the overlap when the same area was burned in different years.

To estimate the environmental threat resulting from the advance of the agricultural frontier, we calculated the percentage of pasture and cropland areas relative to the IL and 
BF areas. For this, we used a 2018 map of land use and land cover of the Amazon derived from the MODIS time series [75].

As an indicator for road access, we calculated the density of roads inside ILs and BFs. For this, we used the road map compiled by the RAISG (Amazon Network of Georeferenced Social and Environmental Information) derived from IBGE (Brazilian Institute of Geography and Statistics) data [76]. The road density was calculated by dividing the sum of road lengths in the IL/BF by the area of the IL/BF $\left(\mathrm{km} / \mathrm{km}^{2}\right)$.

Finally, for quantifying the threat posed by mining, we calculated the number of occurrences of mining activities within and around the ILs compiled by RAISG in 2018 [76]. This dataset aggregates occurrences of mining activities in different cartographic forms of representation, such as polygons that represent areas deforested for mining and detected by remote sensing; points that represent the location records of mining activities; and lines that represent rivers where mining activities have been identified. Given the diversity and richness of this dataset, we grouped all occurrences, of the 3 forms represented into a single indicator.

Table 1. Environmental threats on Amazonian Indigenous Lands, quantification, and data source.

\begin{tabular}{|c|c|c|c|c|}
\hline Where & Threat & Quantification & Period & Source \\
\hline \multirow{7}{*}{ Indigenous Land } & Deforestation & accumulated deforested area (\%) & 1988-2019 & [18] \\
\hline & Forest degradation & accumulated degraded forest area (\%) & 2007-2019 & [70] \\
\hline & Forest fires & accumulated burned area $(\%)$ & 2001-2019 & [74] \\
\hline & Mining & $\mathrm{n}^{\circ}$ of mining occurrences & 2018 & [76] \\
\hline & Agriculture & cropland area $(\%)$ & 2018 & [75] \\
\hline & Livestock & pasture area $(\%)$ & 2018 & [75] \\
\hline & Road access & road density $\left(\mathrm{km} / \mathrm{km}^{2}\right)$ & 2017 & {$[76]$} \\
\hline \multirow{7}{*}{ Buffer Zone } & Deforestation & accumulated deforested area (\%) & 1988-2019 & [18] \\
\hline & Forest degradation & accumulated degraded forest area (\%) & 2007-2019 & [70] \\
\hline & Forest fires & accumulated burned area (\%) & 2001-2019 & [74] \\
\hline & Mining & $\mathrm{n}^{\circ}$ of mining occurrences & 2018 & [76] \\
\hline & Agriculture & cropland area (\%) & 2018 & [75] \\
\hline & Livestock & pasture area $(\%)$ & 2018 & [75] \\
\hline & Road access & road density $\left(\mathrm{km} / \mathrm{km}^{2}\right)$ & 2017 & [76] \\
\hline
\end{tabular}

\subsection{Cluster Analysis}

In this study, we aim to investigate possible patterns in the combination of environmental threats that affect Indigenous Lands in the Legal Amazon region. To this end, we perform cluster analysis of environmental threats in ILs and their surroundings to identify clusters of ILs that share common threats. Cluster analysis is an unsupervised pattern recognition technique that aims to partition a set of data (or objects) into a set of similar groups, often called clusters [77]. In this method, no previous assumptions are made about the clusters, and the areas with similar characteristics, in terms of the values of the variables of interest, are gathered together [78]. The clusters are partitioned according to the distance or similarity between objects in terms of one or more metrics [77], aiming to maximize both intra-cluster homogeneity and inter-cluster heterogeneity [78]. In our study, the objects are the ILs, while the metrics are the quantified environmental threat indicators for each IL and its corresponding BF.

Before the cluster analysis was performed, the following steps were executed. First, we performed logarithmic transformation of quantified indicators to improve the normality of the distribution (in order to deal with the fact that the dataset has zero values for numerous observations, we added a constant value of 0.0001 to the original data for all threats before the logarithmic transformation). Second, we applied z-score standardization to these logarithmic indicators. The z-score standardization method was chosen to improve the accuracy of the K-means algorithm [79], which is a premise of the cluster analysis 
since the analysis is based on the Euclidean distance of the observations [80]. Third, we chose the number of clusters by calculating the coefficient of determination $\left(R^{2}\right)$ from a one-way ANOVA.

We used the partitional K-means clustering algorithm, a commonly used non-hierarchical clustering algorithm. In this algorithm, the number of clusters, $\mathrm{k}$, is determined by the user. Next, $\mathrm{k}$ objects are chosen by an iterative procedure as the centers of the k clusters. Then, all objects are divided among the k clusters according to the measure of similarity adopted, so that each object is in the cluster that provides the shortest distance between the object and the center of the cluster. In the K-means algorithm, the average of the objects belonging to each cluster is used to represent the center of the cluster, also called the cluster's center of gravity [81]. In this study, the square Euclidean distance was used as a measure of similarity.

The most suitable number of clusters was calculated as follows. Initially, the K-means clustering method was performed with different numbers of clusters (2-9). The results of each partitioning were applied in an one-way ANOVA as the dependent variable and the environmental threat indicators as independent variables. From the ANOVA results, the coefficient of determination $\left(\mathrm{R}^{2}\right)$ was calculated by the ratio of the inter-cluster variance (sum of the squares among the groups) and the internal-cluster variance (sum of the total squares for each variable) $[80,82]$. The choice of how many clusters to use was made based on the value of $\left(R^{2}\right)$ in order to optimize the variability gain with the increase in the number of clusters.

All analyses and visualizations were conducted using R [83], ArcGIS 10.4 [84], and Quantum Gis 3.0 [85]. The clustering analysis was performed using the IBM SPSS Statistics software (SPSS) [86].

\section{Results and Discussion}

\subsection{General View of Environmental Threats within and around Indigenous Lands}

Our results show the heterogeneity of environmental threats affecting Amazonian Indigenous Lands and their surrounding areas (Figures 2 and 3). Most of the 383 Indigenous Lands are internally affected by a combination of different environmental threats. Although the threatened ILs are scattered across the Amazon, the ILs affected by multiple and relatively severe threats are located mainly in the arc of deforestation region, in the older frontier areas and in the Roraima state. The arc of deforestation is a region where the highest deforestation rates are mainly caused by the agricultural frontier advancing toward the forest. This territory extends from the west of Maranhão and south of Pará toward the west, crossing through Mato Grosso, Rondônia, and Acre states. This region also has roads such as the BR-163, BR-319, and BR-364 [87] (Figures 2H and 3H).

The threats related to forest loss (deforestation, forest degradation, and fires) are more intensive in the IL buffer zones than inside the ILs (Figures 2 and 3). This result shows, on the one hand, that ILs are effective, in line with other research $[10,88]$, but that their surroundings are drastically affected by deforestation, forest degradation, and forest fires, mainly in the arc of deforestation region and further north (Figure 3). A similar geographical distribution of pasture areas and access by roads can be observed in the buffer zones. Mining occurrences around the ILs can be observed across the Amazon region. Croplands are mainly concentrated around ILs in the arc of deforestation region and Roraima state (Figure 3).

In the consolidated areas, there is a more extensive infrastructure network, which increases the possibility of access to ILs, invasion, and exploration of mineral and forest resources [20,89-91]. Just as the predominant presence of agricultural activity in these areas increases the likelihood that such activities will be extended into the ILs. In the innermost areas of the biome, ILs are less threatened internally and externally, a phenomenon that also seems to be influenced by the ease of access. Although some of them, like Yanomami IL, because of mining, are more threatened even in more remote regions. 
A

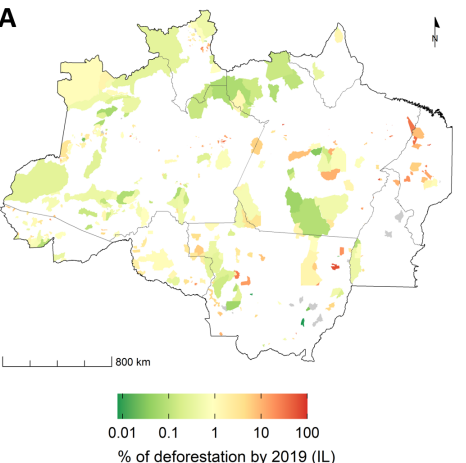

C

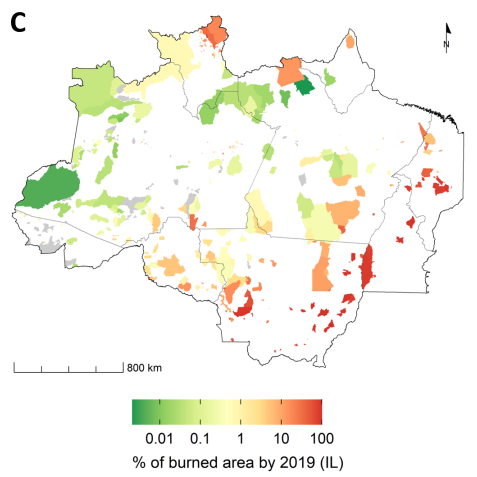

E

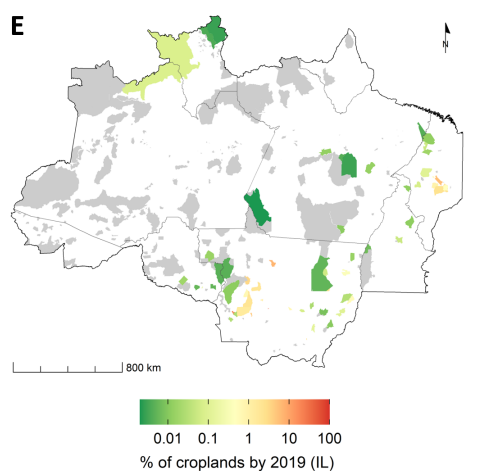

G

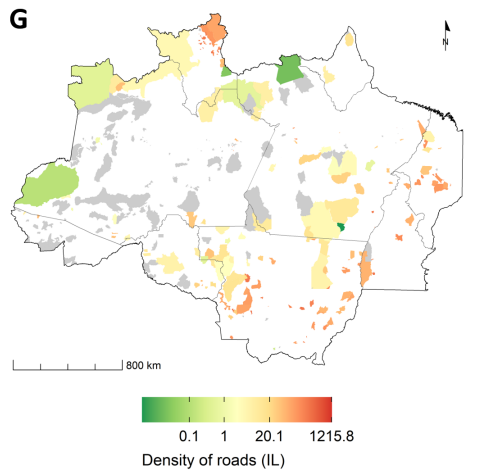

B

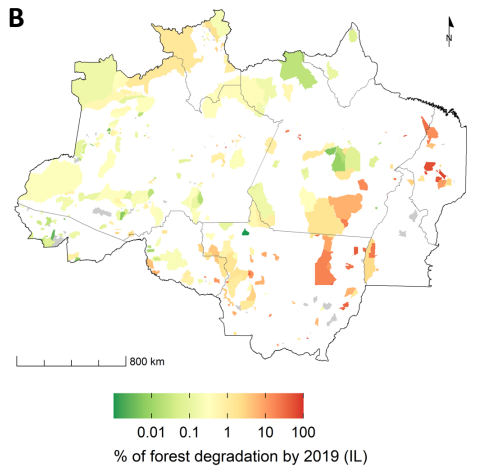

D

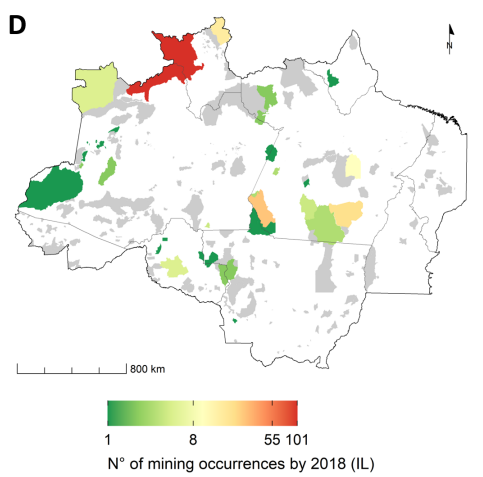

F

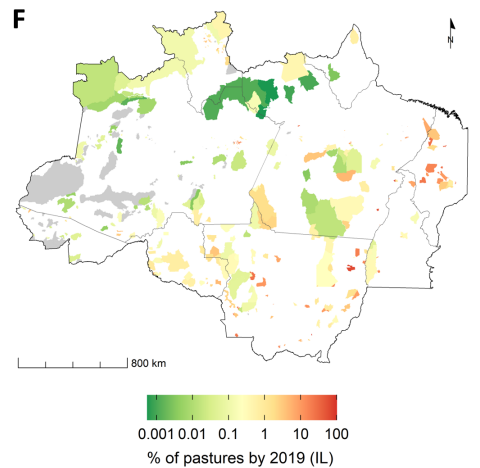

H

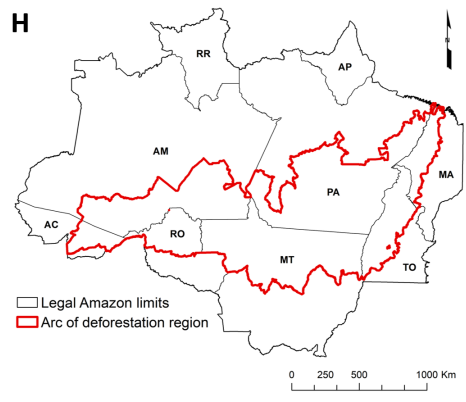

Figure 2. Environmental threats inside Indigenous Lands. Accumulated deforestation by 2019 (\%) (A); Accumulated forest degradation by 2019 (\%) (B); Accumulated burned area by 2019 (\%) (C); Number of mining occurrences by 2018 (D); Croplands by 2018 (\%) (E); Pasture by 2018 (\%) (F); Road density $\left(\mathrm{km} / \mathrm{km}^{2}\right)(\mathrm{G})$; and the Legal Amazon region limits $(\mathrm{H})$. The maps are displayed on a logarithmic scale. Gray indicates 'threat value' $=0$. Data sources are provided in Table 1. 
A

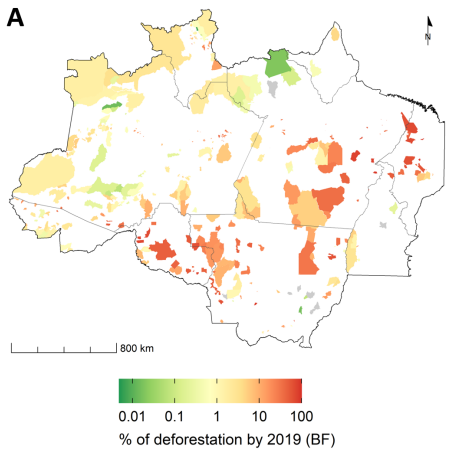

C

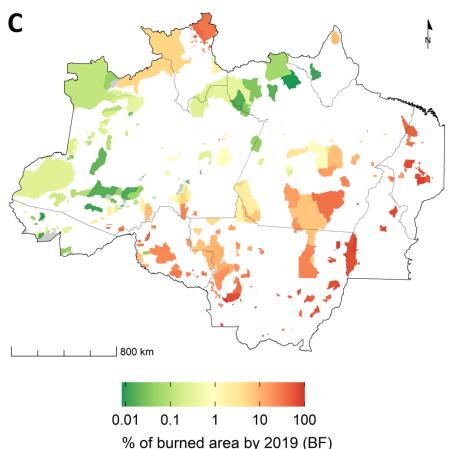

$\mathbf{E}$

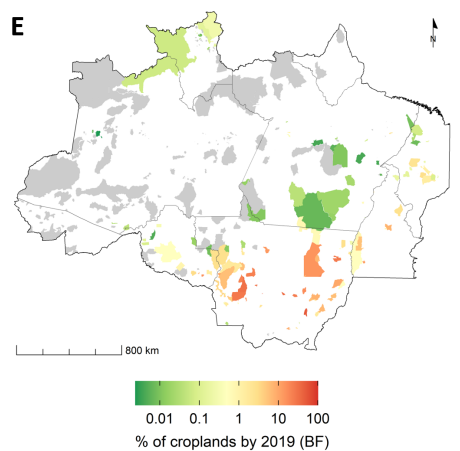

G

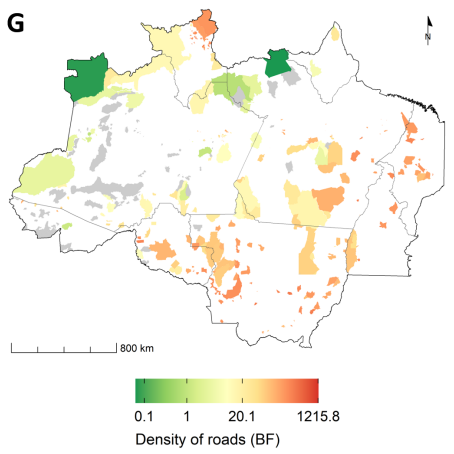

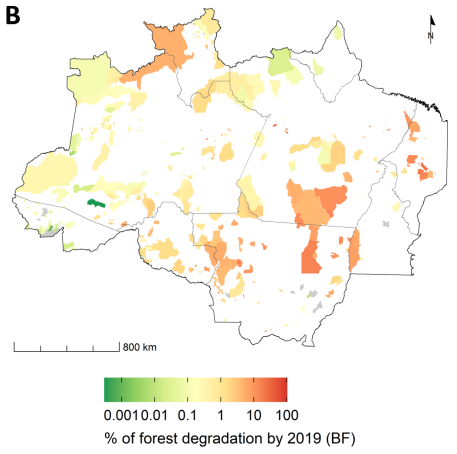

D

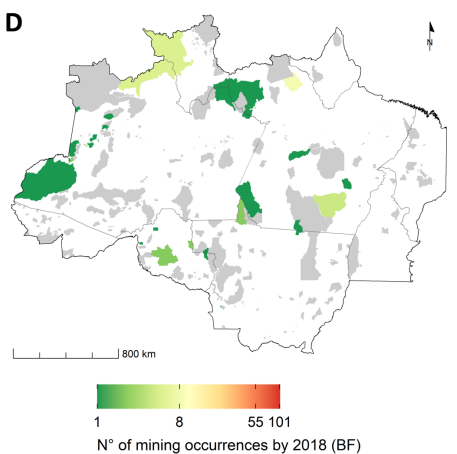

$\mathbf{F}$

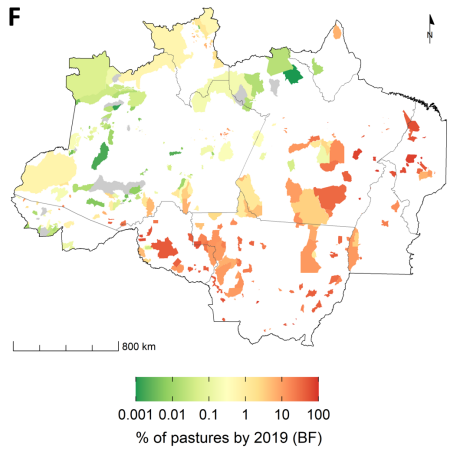

H

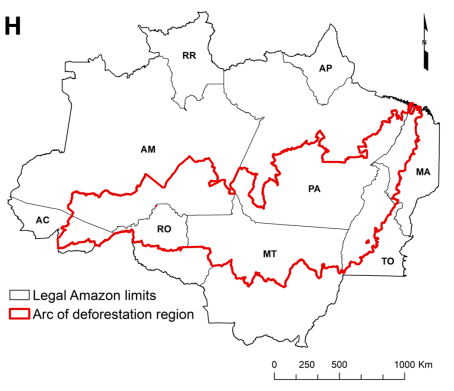

Figure 3. Environmental threats in the buffer zone of Indigenous Lands. Accumulated deforestation by 2019 (\%) (A); Accumulated forest degradation by 2019 (\%) (B); Accumulated burned area by 2019 (\%) (C); Number of mining occurrences by 2018 (D); Croplands by 2018 (\%) (E); Pasture by 2018 (\%) (F); Road density $\left(\mathrm{km} / \mathrm{km}^{2}\right)(\mathbf{G})$; and the Legal Amazon region limits $(\mathbf{H})$. The maps are displayed on a logarithmic scale. Gray indicates 'threat value' $=0$. Data sources are provided in Table 1. 


\subsection{Clusters of Indigenous Lands}

The coefficient of determination $\left(R^{2}\right)$ increased rapidly with the number of clusters until cluster number seven $\left(R^{2}=0.62\right)$; after this, the gain in $R^{2}$ became small (Figure 4 ). Therefore, we applied $\mathrm{k}=7$ clusters in our analysis. The seven clearly separable clusters represent combinations of common environmental threats within and around the ILs (Figure 5). The characteristics of each cluster are described below.

Cluster 1 stands out for the low intensity of threats inside and around the ILs (Figures 6A and A1; Table A2). The predominant threats in this group are deforestation and forest degradation inside and around the ILs. Forest fires, pasture, and roads also appear in this group (inside and outside) with lower severity (Figures 6A, 7, 8 and A1; Table A2). Cluster 1 has 108 ILs, being the largest group, and covering around 247,350 km², representing about $21 \%$ of the total IL area. The ILs in this cluster are concentrated mainly in the states of Amazonas (AM), Acre (AC), and Pará (PA) (Figure 5).

Cluster 2 is characterized by the prevalence of mining as a major threat both inside and outside ILs (Figures 6B, 7D, 8D and A1; and Table A2). In this cluster, the ILs also are affected internally and externally by deforestation, forest degradation, fires, pastures, and roads (Figures 6B and A1; Table A2). Cluster 2 has 25 ILs widely distributed in different states in the Amazon region, covering an area of about 525,384 $\mathrm{km}^{2}$ (44.7\%) (Figure 5). This cluster consists of Indigenous Lands with large territories, such as Yanomami (RR and AM) with 9665 thousand ha, Vale do Javari (AM) with 8544 thousand ha, Menkragnoti (PA) with 4914 thousand ha, and Mundukuru with 2382 thousand ha. The Yanomami, Mundukuru, and Kayapó ILs are among the most affected by illegal mining activities [22].

The ILs in cluster 3 are mainly characterized by deforestation inside their limits and deforestation and roads in the ILs' buffer zones (Figures 6C, 7, 8 and A1; Table A2). Inside the ILs of cluster 3, forest degradation, fires, and pastures also are present but in lower intensity. This cluster also has a high prevalence of pasture, fires, and forest degradation in the ILs' surroundings. Cluster 3 has 79 ILs scattered throughout the Legal Amazon region (Figure 5) covering an area of $127,173 \mathrm{~km}^{2}(10.8 \%)$.

Cluster 4 has a greater severity of most threats inside and outside the ILs, with emphasis on the higher prevalence of cultivation areas, pastures, and forest degradation in this group in relation to the others (Figures 6D, 7, 8 and A1; Table A2). Cluster 4 ranks second in terms of the size of burned areas, just behind cluster 5 . The other predominant threats in this cluster are roads and deforestation inside and outside ILs. The 28 ILs in this cluster cover an area of $38,380 \mathrm{~km}^{2}(3.3 \%)$ and are concentrated mainly in the states of Mato Grosso (MT) and Maranhão (MA) (Figure 5). Mato Grosso is the largest producer of soybeans, maize, and cotton and has the largest cattle herd in Brazil [92,93], while Maranhão is the second-largest agricultural producer in the Northeast region, producing mainly soybean and corn [92]. This means that cluster 4 ILs are under tremendous pressure from agribusiness.

Cluster 5 stands out for presenting the highest amount of burned areas and high density of roads inside and outside the ILs (Figures 6E, 7, 8 and A1; Table A2), in addition to being composed predominantly of small ILs (Figure 5). Within and around the ILs, pastures and crops also predominate. Cluster 5 has 24 Indigenous Lands, totaling an area of about $15,223 \mathrm{~km}^{2}(1.3 \%)$. Most of these ILs are in the region of the arc of deforestation, in areas of the consolidated agricultural frontier in Mato Grosso (MT) and Tocantins (TO), and some in the Roraima state (RR) (Figure 5). This cluster indicates that ILs inserted in consolidated agricultural regions are vulnerable to fire. 


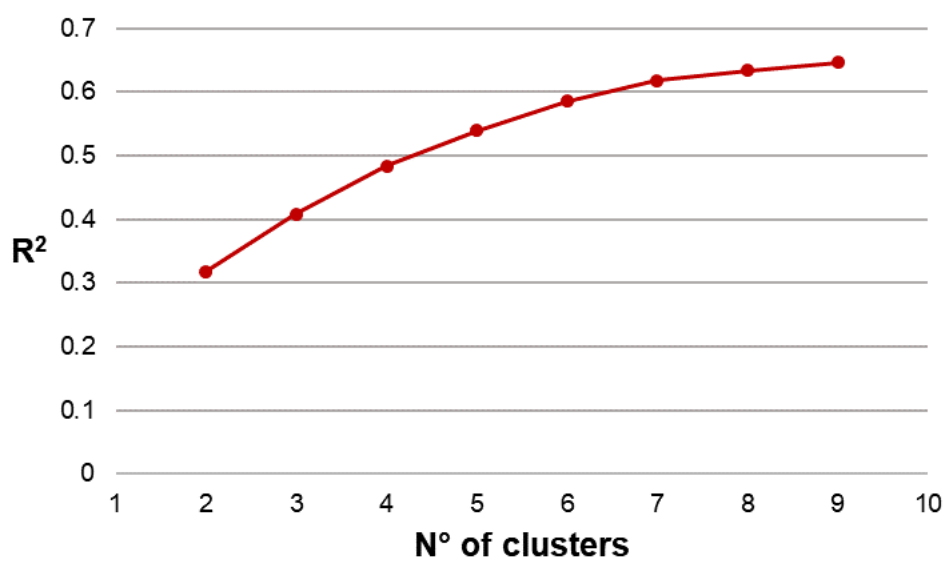

Figure 4. Coefficient of determination of the number of clusters.

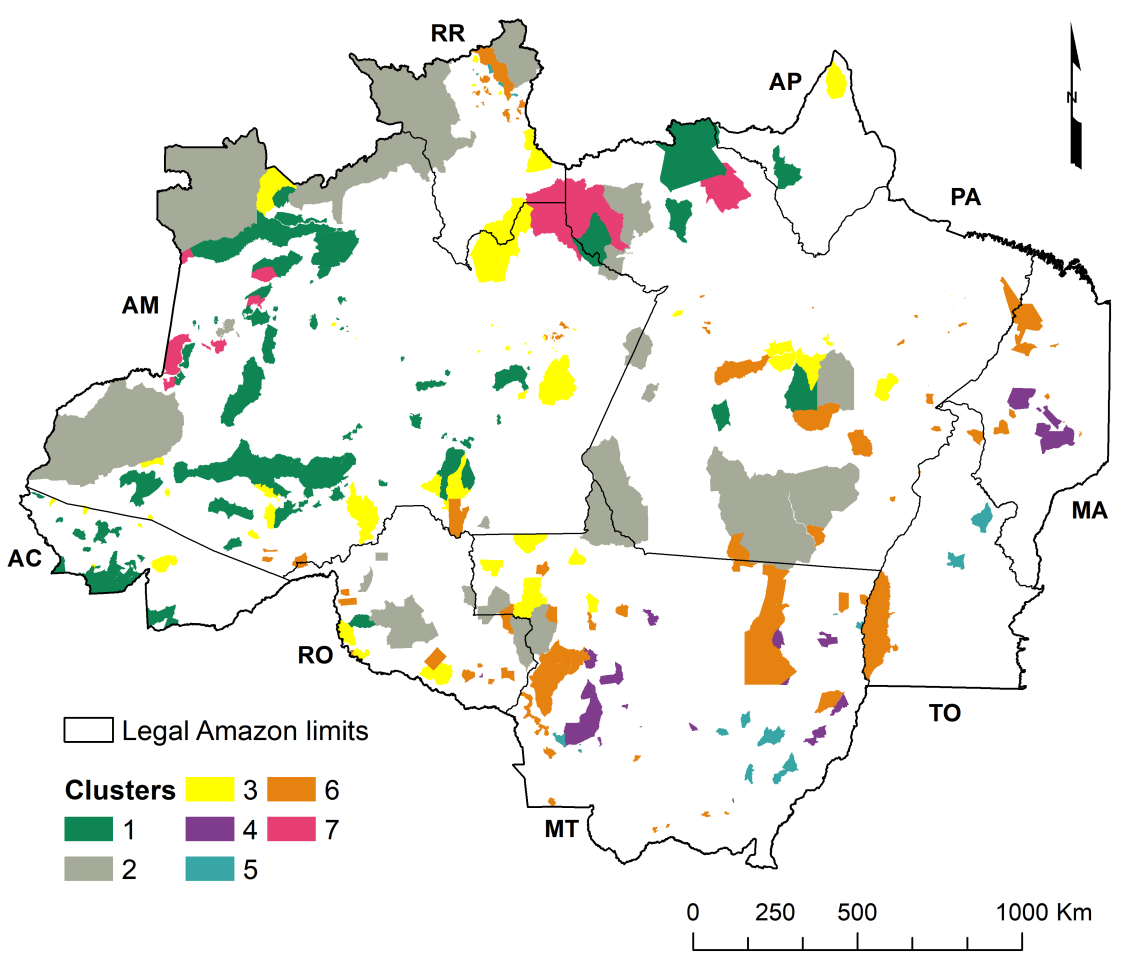

Figure 5. Final clusters of Indigenous Lands according to the set of common environmental threats inside and outside these territories.

Cluster 6 is characterized by high severity for most threats, inside and outside ILs, with minor predominance of crops and mining (Figures 6F, 7, 8 and A1; Table A2). This cluster faces intense pressure from deforestation, shown by the fact that it has the highest median deforestation value inside and outside ILs (Figures 7A and 8A). Cluster 6 ranks second in terms of forest degradation and pasture inside IL, just behind cluster 4. Cluster 6 is also the third most threatened by fires (Figures 7C and 8C). The 103 ILs in Cluster 6 are mainly located in the arc of deforestation and in Roraima state (close to the BR-433 road) (Figure 5) and cover an area of $155,608 \mathrm{~km}^{2}(13.3 \%)$.

Cluster 7 is mainly characterized by the predominance of mining in the ILs' buffer zones (Figure 6G and Table A2). The ILs in this cluster also face deforestation inside and outside their limits, as well as forest degradation, fires, pastures, and roads in the ILs ${ }^{\prime}$ buffer zones with lower intensity. The 16 ILs in cluster 7 are distributed further north of the Amazon region, in the states of Amazonas (AM) and Pará (PA) and, therefore, further from the arc of deforestation (Figure 5). These ILs cover about $65,018 \mathrm{~km}^{2}(5.5 \%)$. 
A

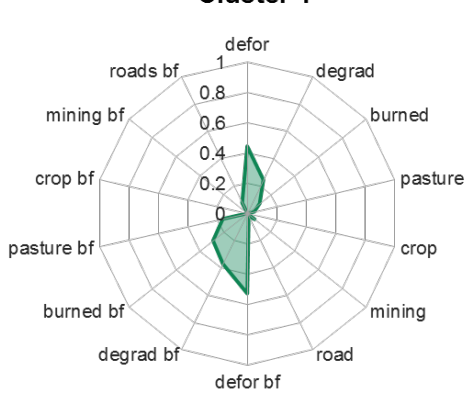

C

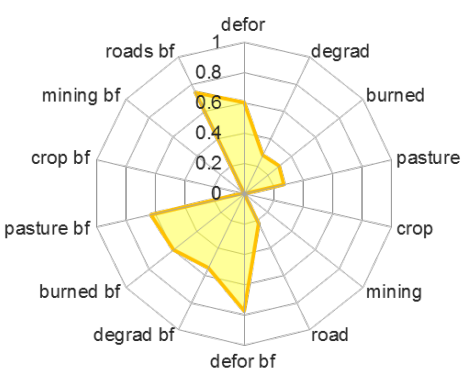

E

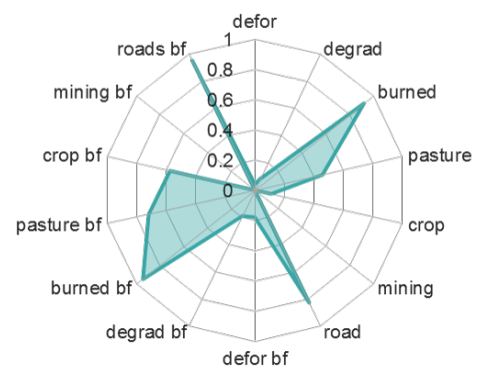

G

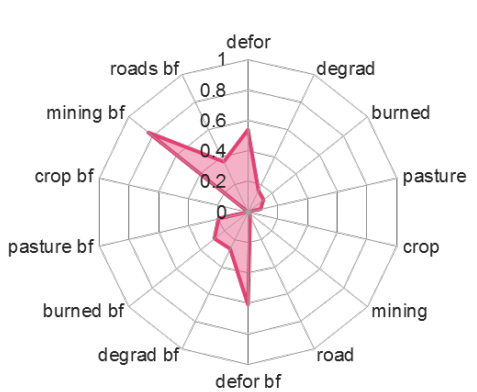

B

Cluster 2

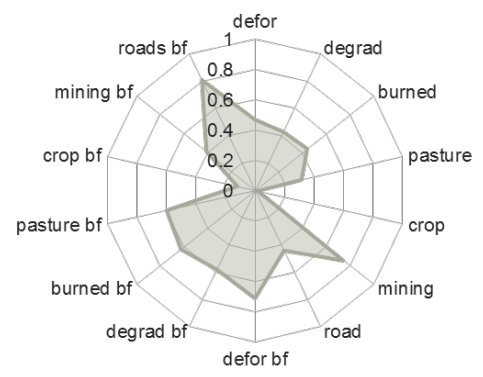

D

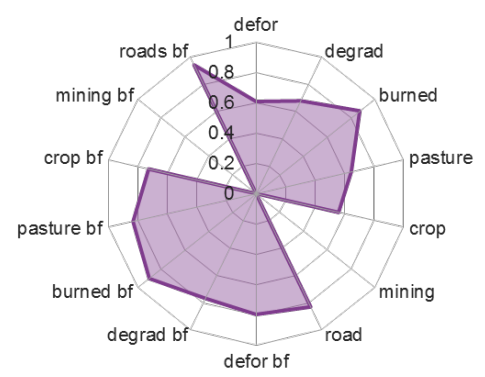

$\mathbf{F}$

Cluster 6

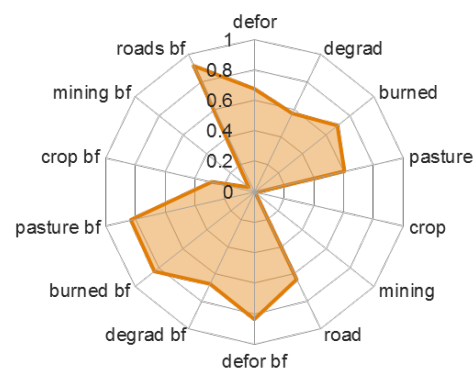

Figure 6. Radar charts of the clusters of Indigenous Lands (A-G). The values are plotted to represent the the mean of each threat for each cluster. To improve the visualization of the results in this graph, we apply the logarithmic transformation followed by scaling between 0 and 1 (using the min-max method) on the original variables. The central axis delimits the environmental threats in the buffer zone (left) and within the Indigenous Land (right). Threats in the buffer zone are identified by the abbreviation 'bf'. The term 'defor' is an abbreviation for deforestation and 'degrad' for forest degradation. 

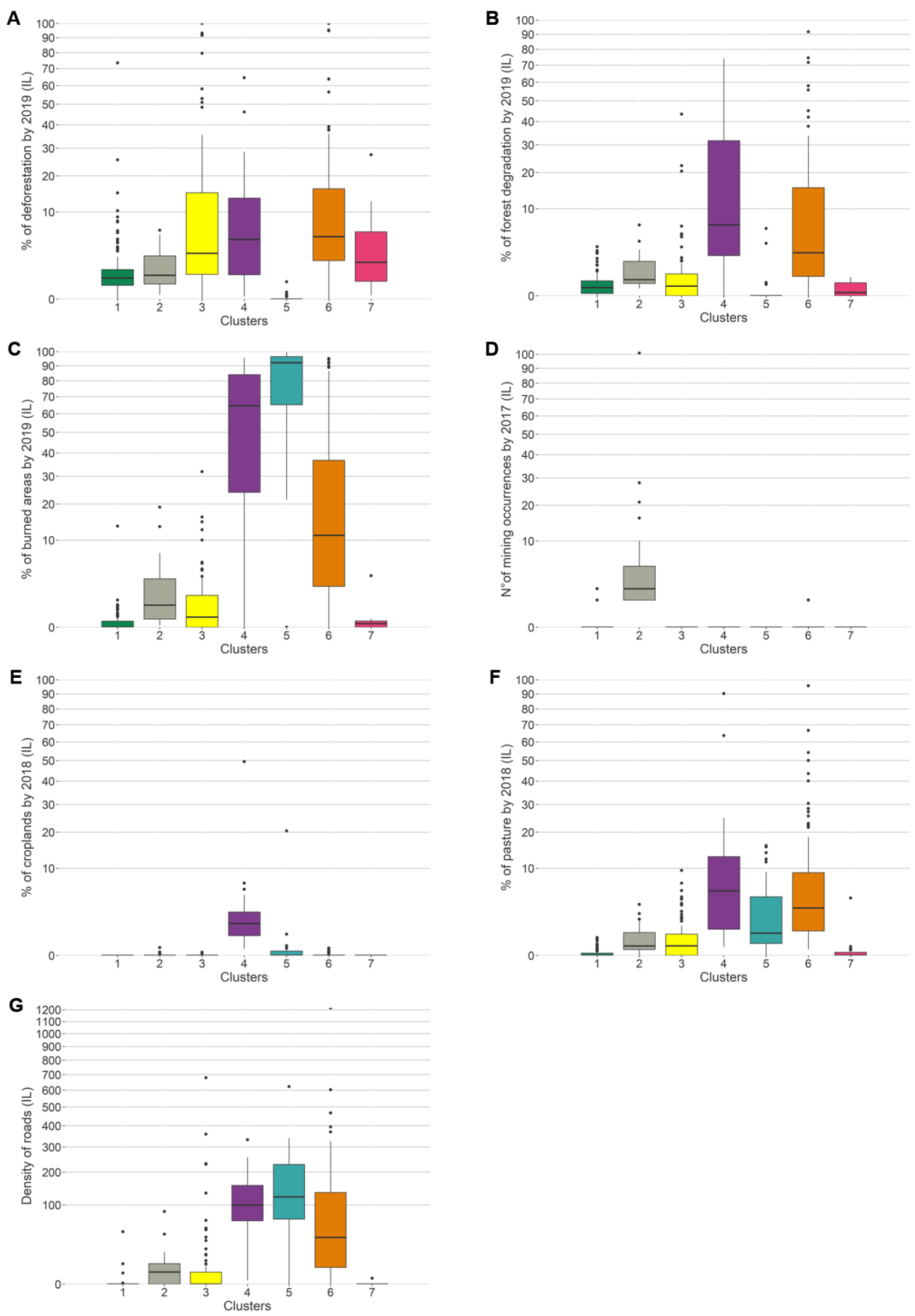

Figure 7. Boxplots of environmental threats within Indigenous Lands (IL). Accumulated deforestation by 2019 (\%) (A); Accumulated forest degradation by 2019 (\%) (B); Accumulated burned areas by 2019 (C); Number of mining occurrences (D); Croplands by 2018 (\%) (E); Pasture by 2018 (\%) (F); Road network density $\left(\mathrm{km} / \mathrm{km}^{2}\right)(\mathrm{G})$. The axes increase quadratically to improve the visibility of differences. The upper and lower whiskers correspond to the first and third quartiles, and the line inside the box represents the median. Data beyond the end of the whiskers are outliers and plotted as points. 
A 1

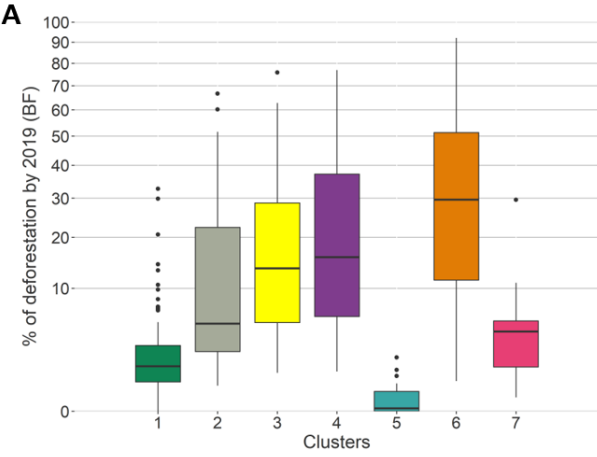

C

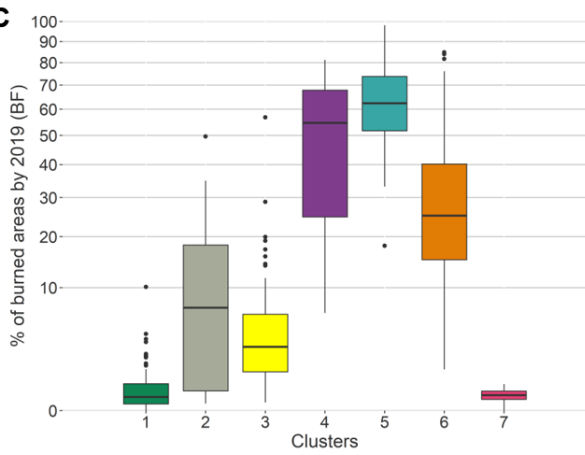

E

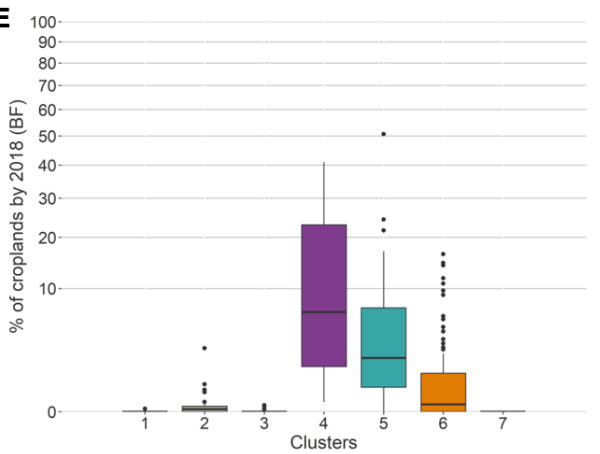

G

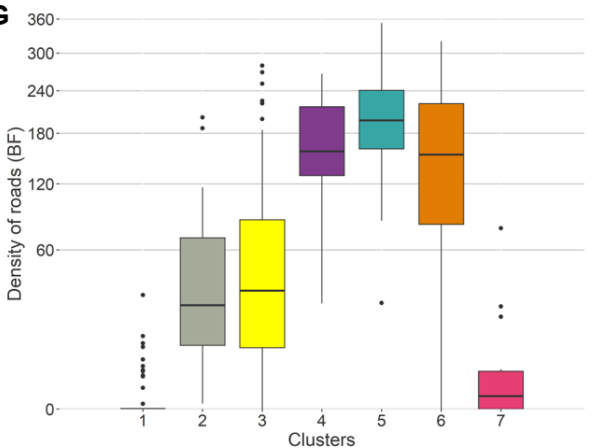

B

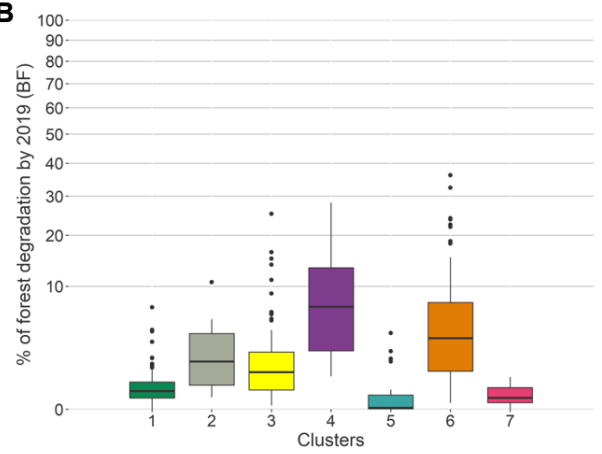

D

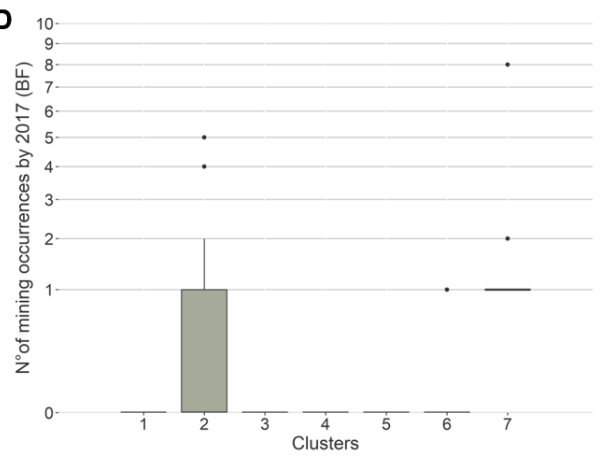

F 100

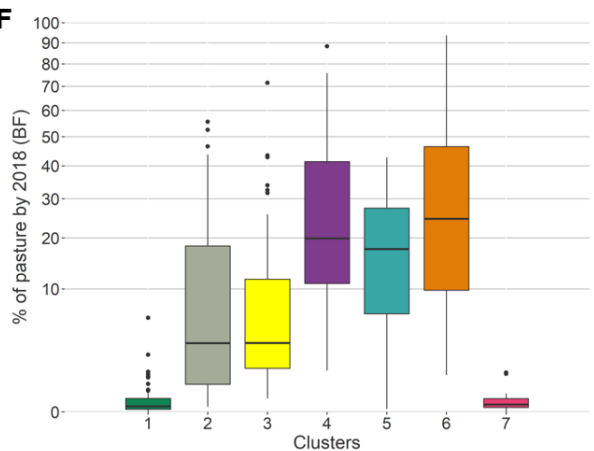

Figure 8. Boxplots of environmental threats in the buffer zone (BF) of Indigenous Lands. Accumulated deforestation by 2019 (\%) (A); Accumulated forest degradation by 2019 (\%) (B); Accumulated burned areas by 2019 (C); Number of mining occurrences (D); Croplands by 2018 (\%) (E); Pasture by $2018(\%)(F)$; Road network density $\left(\mathrm{km} / \mathrm{km}^{2}\right)(\mathrm{G})$. The axes increase quadratically to improve the visibility of differences. The upper and lower whiskers correspond to the first and third quartiles, and the line inside the box represents the median. Data beyond the end of the whiskers are outliers and plotted as points. 


\subsection{Public Policies to Protect the Environmental Integrity of Indigenous Lands}

Based on our results, we have identified four priorities for environmental policies regarding Amazon ILs:

1. Protecting the ILs' buffer zones throughout the Amazon, as demonstrated by all clusters (Figures 3, 6, 8 and A1);

2. Combating illegal deforestation, forest degradation, and mining within ILs throughout the Amazon region, as demonstrated by clusters 3, 4 and 6 for deforestation and forest degradation (Figures 6 and 7A,B) and by cluster 2 for mining (Figures $6 \mathrm{~B}$ and 7D);

3. Preventing and combating fires (within IL and BF) in the arc of deforestation region and the Roraima state, as demonstrated by clusters 4,6 and mainly 5 (Figures 2C, 3C, 6, 7C and 8C);

4. Removing invaders of all Amazon ILs, starting with those present intense agricultural activities (crops and pasture) demonstrated by clusters 4,5 and 6 ; and intense mining, such as cluster 2 (Figures 6 and 7E,F).

Brazil has a robust set of environmental legal regulations built over decades because of the struggle of different national society sectors, including Indigenous peoples. The protection and combating of environmental threats in Amazon Indigenous Lands depend on the execution and efficiency of a set of public policies in line. As such, first, it is necessary to identify the main sets of environmental threats that affect each IL. Taking into account the specificities of threats is important to subsidize the development of differentiated public policies to control, prevent, and combat current and future impacts.

From 2003 to 2013, active public policies reduced deforestation in the Amazon region by $80 \%$ and also substantially improved indigenous peoples' rights, including the demarcation and creation of protected areas. In the next sections, we discuss the importance and the precariousness of the most important environmental policies to stop the advancing environmental threats to Amazon Indigenous Lands and how these policies need to be restored and strengthened. Herein, we refer to historic policies as these have proven effective. We argue that it is precisely during the dark times, in which government is going in the opposite direction, that we must prepare for change. Despite many imperfections, Brazil is still a working democracy, where regular elections are held. Sooner or later, the current government will be out of office; it is all the more important that a more environmental-friendly government is supported by good and efficient policy.

\subsubsection{Protecting Indigenous Lands' Buffer Zones}

As evidenced by our results, the environmental threats and their impacts around the Indigenous Lands are substantial (Figures 3 and 8). The set of threats in the buffer zone are very similar to the set of threats that affect Indigenous Lands internally (Figure 6). In this way, there is a need to reinforce the surveillance and control of environmental threats affecting all ILs' buffer zone, mainly those in clusters 4,5 , and 6 .

According to the law, the occurrences of illicit environmental acts around ILs and that have the potential to impact them must be monitored by FUNAI and dealt with by competent agencies, such as IBAMA (Brazilian Institute of the Environment and Renewable Natural Resources) [1]. Further, the Interministerial Ordinance No. 60 of 2015 determines the need for environmental licensing for activities that may affect Indigenous Lands, establishing a minimum distance required for different activities (e.g., mining $=10 \mathrm{~km}$ ) or infrastructure projects (e.g., roads $=40 \mathrm{~km}$ ). This measure aims to guarantee the integrity of ILs and their ecosystems by protecting their surroundings [73]. However, according to the severity of the environmental impacts observed around the ILs from our results, the combination of these policies appears to be insufficient. We highlight that actions aimed at controlling and combating environmentally illicit activities in ILs' surroundings must be strengthened. We argue that the buffer zones around these territories must be established with stricter environmental rules, potentially protecting ILs against the advancement of degrading activities. 


\subsubsection{Preventing and Combating Illegal Activities in Indigenous Lands}

In Brazil, the surveillance and protection of ILs' environmental integrity are obligations of the State and comprise a set of command and control actions to curb illegal activities. FUNAI carries out surveillance actions on ILs in partnership with other government agencies with police power. Among the partner agencies, those that stand out are the Federal Police, in the control of the judicial police; the IBAMA, in actions of environmental competence; the ICMBio (Chico Mendes Institute for Biodiversity Conservation), in the areas overlapping the UCs; the Military Police of the states, in the occurrence of crimes against the individual; the INCRA (Institute for Colonization and Agrarian Reform), for dealing with land tenure and displacement of occupants; the Armed Forces of Brazil (composed of the Army, Navy and Air Force); and the Environmental Military Police [1].

The main surveillance and combat actions in the ILs are aimed to fight deforestation, selective logging, and illegal mining; repress illegal hunting and fishing; and extrude invaders. Here, we aggregate the combating of deforestation, selective logging, and illegal mining because of the policy similarities employed to address these threats. The latter, namely extruding invaders, will be discussed in a separate Section 4.3.4.

While these agencies' integrated work helped combat illegal deforestation in the Amazon before 2012 [94,95], staff and budget cuts have weakened their ability to enforce environmental laws $[32,33,38]$. The substantial weakening of policies to combat illicit activities and the dismantling of environmental surveillance agencies (IBAMA and ICMBIO) and FUNAI is an issue of concern in Brazil. In general, these agencies are currently without a budget and sufficient personnel to carry out combat and control actions in ILs. These agencies' dismantling can partially explain the observed increase of deforestation, fires, and exploration of natural resources in the Amazon and ILs in recent years $[18,19,30,31,70]$. While in 2009 IBAMA had around 1600 agents across Brazil, in 2019 that number dropped to 780 employees [38]. Likewise, FUNAI's number of employees has been reduced by about 30\% since 2012, from 3111 to 2224 in 2019 [38].

According to the Human Rights Watch report, in 2018, IBAMA had only nine field agents to monitor many environmental crimes in the Maranhão state [38]. The Indigenous Lands of Maranhão preserve the largest Amazonian forest blocks in the state and are the target of intense environmental degradation [96], with high levels of accumulated deforestation, fire, and forest degradation, as demonstrated by clusters 4 and 6 . The illegal occupation of squatters and loggers is high in these ILs and causes intense conflicts, having resulted in the murders of several Indigenous leaders [30,31,67]. This reflects how the State currently neglects vast forest areas in the Amazon and the Indigenous peoples' rights.

Furthermore, these agencies have also lost their operational autonomy. First, career agents with technical experience and those responsible for combating and controlling environmentally illicit activities were removed from their positions and replaced by military personnel with no technical experience. Second, actions to combat environmental illegal acts in the Amazon are now being coordinated by the National Council of the Amazon through intense action by the armed forces, creating a situation of subordination by FUNAI and IBAMA. However, since implementing this new structural arrangement to combat the Amazon's environmental threats, the program has proved inefficient. In the years of 2019 and 2020, the Amazonian ILs saw the highest records of deforestation, forest fires, invasions, and resource exploitation [18,19,30,31]. We argue that IBAMA must be reinstated to its full competence to manage environmental policies combating illegal deforestation and other activities in these territories. With budgetary and personnel support, this agency's autonomy has already proved to be efficient for fulfilling its function [94].

Another point that weakens Brazilian environmental policy and encourages illegal activities is the new regulation created regarding fines against environmentally illicit acts (Decree 9760). According to the new regulations, environmental fines must be reviewed at conciliation hearings, in which discounts can be offered or fines can even be declared null. Further, the the payment of fines only happens after the conciliation hearing, causing a substantial delay in collecting fines. Given the structural degradation of environmental 
agencies nowadays, most hearings may not even happen in time, leading to the fine's expiration and cancellation. In 2020, of about 1000 fines imposed by IBAMA for illegal deforestation in the Amazon, only 3 were paid. Thus, instituting fines that, in practice, do not need to be paid cannot help curb environmental crimes $[38,97,98]$.

Illegal mining, deforestation, and illegal logging activities in the Amazon involve a complex logistics chain with high-cost machinery and labor. These activities are orchestrated by organized criminal organizations $[38,99]$ that are also responsible for the illegal opening of roads in ILs and other federal forests and the organization of export schemes for illegal products, which thus bypass any inspections [38,100]. We argue that policies to combat these criminal networks must be strengthened both from the bottom up (combating illicit acts in the field, destroying machinery, and punishing the offenders) and from the top down, through punishing the powers behind these organizations. The Public Ministry has a large role in investigating these criminal networks in order to contain threats that degrade the Amazon rainforest.

\subsubsection{Preventing and Combating Fires in Indigenous Lands}

Policies for preventing and combating fires in Indigenous Lands are established mainly through the program Federal Brigades in Indigenous Lands, a cooperation agreement established in 2013 between FUNAI and the National Center for the Prevention and Fighting of Forest Fires (Prevfogo) from IBAMA [50,101]. This program aims to select, train, and hire Indigenous brigadiers to monitor and fight fires in their territories. The program also supplies equipment, vehicles, and logistics for work, and the brigades may be dispatched to other Indigenous Lands if necessary. The brigades are formed by Indigenous people, supported by FUNAI's and IBAMA's employees, who combine traditional knowledge with non-Indigenous fire management techniques to reduce the socio-environmental impacts caused by uncontrolled fires $[1,50]$.

The Indigenous brigades have played an important role in preventing and fighting forest fires in the Amazonian ILs. An important part of the brigadiers' activities is focused on preventive actions with prescribed and controlled burning, the opening of firebreaks, and the cleaning of land, together with the recovery of degraded areas [50]. The firefighters in ILs can count on reinforcement from the Military Fire Brigade and non-Indigenous brigadiers as well.

In the past two years, forest fires in ILs and their surroundings have increased [19]. These fires are mainly caused by the activities carried out around the ILs, which trigger uncontrolled fires toward these territories. Two important causes for the spread of fire in ILs are the practice of surrounding farmers burning their pastures and the practice of burning vegetation in order to open new areas. This points to the need to control and inspect the ILs' surroundings and punish those responsible for fires that affect ILs. In addition, according to reports by Indigenous leaders from different ILs in the Amazon, the uncontrolled fires that affect these territories are often the result of criminal actions inside the ILs, who aim to open certain areas for land exploration. These activities are partly encouraged by government discourse and the lack of vigilance and punishment [102]. Although environmental agencies must identify and punish those responsible for spreading fire on ILs, their field combat activities and the effectiveness of fines have been weakened.

Despite the importance of the Indigenous Brigade Program and the excellent results it has produced, currently, its scope and execution have proven to be inefficient. Because of the dismantling of the agencies responsible for implementing this program, FUNAI and IBAMA, and the lack of resources and personnel, this program does cannot strongly support all the brigades in the various ILs. Thus, in many ILs, Indigenous peoples struggle to put out fires on their own without logistics and State support [53,54]. As a result, the negative impacts of forest fires in these territories have been increasingly greater. 
We argue that support must be provided for the Indigenous Brigades to control and combat forest fires efficiently. Thus, it is necessary to restructure the agencies responsible for this program, namely IBAMA and FUNAI, to re-establish their autonomy and increase the budget and personnel. Additionally, greater attention should be paid to the ILs of clusters 4, 6, and 5 mainly.

Finally, the ILs with a predominance of cerrado vegetation have a history of greater occurrences of uncontrolled fires, due the natural dynamics of this vegetation but also due to traditional fire management practices. For a long time, fire suppression was considered the best strategy in these regions. Over the years it has been realized that an Integrated Fire Management (IFM) policy could be more appropriate [103]. In line with the Indigenous Brigades program, several IFM initiatives have been developed in Brazil, to reintroduce fire as a management tool, mainly in Cerrado biome. Such a policy could be strengthened in ILs of clusters 4, 5 and 6 with a predominance of cerrado vegetation and susceptibility to fire.

\subsubsection{Extrusion of Illegal Non-Indigenous Invaders of Indigenous Lands}

Extrusion is a legal measure that guarantees Indigenous territorial rights, allowing non-Indigenous occupants to be removed [1,3]. This process has been established to remove people who practice illegal activities in Indigenous Lands, such as squatters, gold miners, and loggers, among others; or after the regularization of Indigenous Lands [1]. The law guarantees the extrusion and proves to be a necessary and effective measure to contain the environmental degradation developed by illegal activities within ILs and to guarantee the protection, safety, and the exclusive right of Indigenous peoples to usufruct their lands.

The extrusion of invaders has already been carried out for some Indigenous Lands under intense occupation by non-Indigenous people, such as Awá IL in Maranhão in 2014 and Marãiwatsédé IL in Mato Grosso in 2012 [1]. However, the process of extrusion often takes several years to be concluded, and the lack of inspections has resulted in the return of invaders who act illegally within these territories. For example, recently the Brazilian Justice ordered that the process of extruding invaders from Apyterewa IL must resume, a process that started in 2011 [104]. This year, the Federal Supreme Court decreed that non-Indigenous people from Cachoeira Seca IL in Pará and Yanomami IL in Roraima be extruded. In Cachoeira Seca IL, squatters have occupied this IL and have primarily developed agricultural activities. In Yanomami IL, several miners have invaded; currently, about 20,000 illegal gold miners operate in Yanomami IL, resulting in serious socio-environmental impacts, including contaminating the Indigenous population with mercury and spreading COVID-19 [105,106].

We argue that removing invaders from Indigenous territories is an essential legal measure to combat illegal activities within these lands. Much of the activities that generate environmental degradation and make Indigenous populations vulnerable could be combated with the intense removal and punishment of these illegal invaders. Furthermore, these territories must be constantly monitored after the extrusion process so that invasions do not recur. The extrusion of invaders should be directed toward ILs with large settlements and agricultural activities (cluster 4, 5 and 6), which lead to continuous illegal occupation and deforestation of new areas in order to expand illegal activities, and to ILs that harbor intense illegal mining activity (cluster 2).

\subsection{Beyond Public Policies}

In addition to the public policies that the State must apply to strengthen the environmental conservation of ILs discussed above, a fundamental role in guaranteeing these territories' integrity lies in the mobilization and self-organization of Indigenous peoples [107]. Historically, Indigenous resistance movements have been important drivers of the country's environmental debate, with a powerful presence alongside environmental movements. Due to both parties' claims and struggle, the country's environmental legislation was strengthened and consolidated [8,16], e.g., via the creation of the Statute of 
the Indian in 1973 [3] and Article 231 of the 1988 Constitution on the rights of Indigenous peoples [2].

Several Indigenous organizations in Brazil are currently responsible for articulating Indigenous demands and putting pressure on the government (e.g., the Articulation of Indigenous Peoples in Brazil (APIB) and the Coordination of Indigenous organizations in the Brazilian Amazon (COIAB)). Important examples of Indigenous movements are related to the resistance against building large infrastructure projects with the potential to impact their territories, like roads and dams. In the Amazon, the building of dams affecting Indigenous territories is a matter of historical struggle, and Indigenous peoples have had to mobilize to defend their territories against environmental degradation [107-109]. Currently, several infrastructure projects are planned to be built in the Amazon region, as the planned roads, dams, and ports in the South American Regional Infrastructure Integration program (IIRSA) [107]. These projects have a high potential to impact the whole Amazon ecosystem, as well as Indigenous territories throughout the region. In addition, there is a potential risk of worsening mining impacts on Amazonian ILs if bill PL 191/2020, which regulates the opening of these territories to economic activities, were to be approved [22].

Around the world, mineral exploration is generally associated with intense socioenvironmental impacts and results in the emergence of conflicts, such as the so-called 'blood diamonds' in Africa and the illegal exploitation that occurs in Amazonian ILs. Measures adopted to inspect and regulate the supply chain of diamonds in Africa, such as an international certification scheme for rough diamonds (the Kimberley Process Certification Scheme) [110], have shown good results. This experience can be a possible path for the Amazonian gold supply chain so that mining on Indigenous lands is curbed.

The empowerment of Indigenous peoples is recognized worldwide as an important weapon in the fight against climate change, to Amazon conservation [107] and to achieve the Sustainable Development Goals established by the United Nations. Assuring land tenure for Indigenous peoples and supporting their rights have already proved efficient to preserve tropical forests and is considered a positive cost-benefit policy for the country $[8,111,112]$. Further, the involvement of Indigenous peoples in the environmental management of ILs based on their traditional knowledge and supported by the State has great potential to guarantee the survival and maintenance of their ways of life associated with environmental conservation. A good initiative in this area was elaborating the National Policy for Environmental and Territorial Management of Indigenous Lands (PNGATI-Decree No. 7.747/2012), with the active participation of Indigenous peoples across the country [113]. The PNGATI provides that the territorial and environmental management of ILs must be carried out by the Indigenous peoples themselves, with autonomy and the State's active support. Within the scope of the PNGATI, each IL must have its own Environmental and Territorial Management Plan elaborated by the resident Indigenous peoples in partnership with governmental and non-governmental entities, aiming to reconcile traditional Indigenous knowledge and the technical support of non-Indigenous knowledge. However, most Amazonian ILs currently lack this plan [114]. The capacity of Indigenous peoples to cope with environmental threats to their territories is linked with the quantity and quality of resources they have, especially regarding the access to knowledge, the established partnerships, and the accesses to financial resources to carry out IL management. We highlight the urgency of strengthening PNGATI so that Indigenous peoples can be effective actors in the management and environmental protection of Amazonian ILs.

The land tenure regularization of ILs has been an important factor to contain environmental degradation in these territories $[17,112]$. However, the new Normative Instruction 9/2020 makes some ILs more vulnerable to environmental threats than others. According to this regulation, areas occupied illegally by non-indigenous squatters can be certified by FUNAI to be in their possession even within Declared and Delimited ILs [115]. The Delimited and Declared ILs (Figure 1) that are part of clusters 4, 5, and 6 (Figure 5) suffer intense internal and external environmental threats, and, given this regulation, they are more vulnerable. This measure significantly weakens the guarantee of the right to land 
to Indigenous peoples who traditionally occupy them and who await land regularization. Such a concern situation is reinforced by the fact that 297 ILs throughout Brazil, under different regularization phases, have part of their legal territory registered with the Rural Environmental Registry (CAR) in the name of private individuals or entities [116]. In total, 7739 rural properties included in the CAR overlap with the ILs throughout the country, totaling more than $12,000,000$ hectares [116].

Finally, several examples of Indigenous mobilization for monitoring and protecting their territories are known in Amazonian ILs, such as the Guardians of the Forest in the Maranhão ILs and the Mundukuru and Kayapó peoples organization to expel invaders [99]. However, we argue that this is not an Indigenous obligation. According to the current context of high exposure to various threats and invaders and the lack of State support in combating the illegal acts in ILs, Indigenous peoples are left under-supported. Several murders and acts of violence against Indigenous peoples have been recorded in recent years, showing these peoples' high vulnerability. The State cannot abandon Indigenous peoples in the fight against invaders. It is not fair that Indigenous peoples have to face criminal actions alone; such illegal activities should be combated and inhibited by the State.

\subsection{Limitations and Future Work}

We recognize and point out some methodological limitations in our study. First, our approach is limited to the availability of data for different threats. Thus, threats have different time intervals. However, we argue that despite this limitation, the threats considered in this study are represented by the best possible dataset and were compiled in order to establish a correct estimate of these impacts accumulated over the years. Second, the number of $\mathrm{k}$ clusters determined in our analysis importantly influences the classification of Indigenous Lands among the clusters. To avoid any biased influence on this result, we have chosen to establish the number of clusters quantitatively, aiming to optimize the variability explained by the variables. In addition, we verified the partitioning of ILs for other $\mathrm{k}$ values, and, in all of them, the trend of the clusters formation was maintained.

Third, although the formulation of the mining indicator (absolute number of occurrences of mining activity) is different from other threats, which are based on area, we believe that the number of occurrences better represents the magnitude of this activity in the ILs. We argue that restricting mining occurrences only to occurrences related to polygons of deforested areas does not adequately represent the magnitude of this threat; on the contrary, the magnitude of mining would be underestimated if the other occurrences (points and rivers) were disregarded. The alternative of building a variable from dividing the number of mining occurrences by the IL and BF areas was also evaluated, but this indicator can result in equal values for different threat situations, producing a dubious meaning. In addition, mining is a phenomenon whose threat should not only be measured by the area of the mine itself. Instead, it is a phenomenon whose effect goes beyond the area in which it is observed, as it can cause contamination of rivers and soil, and reduce biodiversity, lead to silting, and cause increased contact between non-Indigenous and Indigenous people (due to a large number of people in these activities) $[21,23,69,117]$.

Regarding future works on Amazonian ILs, we suggest that it is important to perform temporal analysis of environmental threats, to assess the dynamics of threats and, perhaps, to link the increase in threats to the dynamics of policies. For example, comparing the dynamics of threats to ILs before and after recent political and institutional changes. Further, future studies should perform an environmental vulnerability assessment of these areas, which should include not only exposure to threats but also the adaptive capacity of Indigenous peoples to lead the fight against these threats. In this case, information about the Indigenous people's capacity of organization and articulation is important, which we did not analyze in the present study. Such a study could contribute to the development of special policies to support Indigenous peoples and mitigate environmental impacts in these territories. 


\section{Conclusions}

Our results contribute to the effort to understand the specificities of Indigenous Lands in relation to multiple environmental threats and highlight the need for targeted public policies. In this study, we identified and characterized seven distinct IL clusters defined by common environmental threats within and around their boundaries. The environmental threats around Amazonian ILs are substantial, and most ILs are internally affected too. In general, the set of threats in the buffer zones are very similar to the set of threats that affect Indigenous Lands internally. There was a cluster specifically associated with fire, one with mining, some with a high severity for several of the investigated threats, and one cluster that was relatively less threatened.

We point out four environmental policy priorities to be strengthened and applied to Amazonian ILs: protecting ILs' buffer zones; strengthening actions of surveillance and combat in ILs with intense deforestation, forest degradation, and mining; preventing and combating forest fires over ILs; removing invaders from all Amazonian ILs, starting with those intensely occupied by miners and squatters. There is an urgent need to curb illegal activities within these territories. The joint action between FUNAI and IBAMA has previously shown good results in inhibiting environmental infractions in the Amazon and in Indigenous Lands. Strengthening surveillance and combating environmental threats within and around the ILs are essential for the effective protection of these territories and to guarantee the promotion of the Amazonian Indigenous peoples' rights.

Author Contributions: Conceptualization, A.C.R., M.C.A.P., J.A.V., G.C., F.G.S.B. and M.I.S.E.; methodology, A.C.R., M.C.A.P., J.A.V., G.C., F.G.S.B. and M.I.S.E.; formal analysis, A.C.R., M.C.A.P.; data curation, A.C.R.; writing-original draft preparation, A.C.R.; writing-review and editing, A.C.R., M.C.A.P., J.A.V., G.C., F.G.S.B. and M.I.S.E.; Supervision, M.C.A.P., J.A.V., G.C., and M.I.S.E. All authors have read and agreed to the published version of the manuscript.

Funding: This study was funded in part by the Coordenação de Aperfeiçoamento de Pessoal de Nível Superior-Brasil (CAPES)—Finance Code 001. As well as, by the Co-financed Short-Term Research Grant Brazil, 2019 (57479963) - A joint agreement between German Academic Exchange Service (DAAD) and Coordenação de Aperfeiçoamento de Pessoal de Nível Superior (CAPES). We would also like to thank Celeste Brennecka for editing of English language.

Conflicts of Interest: The authors declare no conflict of interest.

\section{Abbreviations}

The following abbreviations are used in this manuscript:

IL Indigenous Land

BF buffer zone

defor deforestation

degrad forest degradation

\section{Appendix A}

Table A1. Stages of the recognition process of Indigenous Lands in Brazil. Source: FUNAI.

\begin{tabular}{ll}
\hline Stage & Description \\
\hline In study & $\begin{array}{l}\text { Conducting anthropological, historical, land, cartographic and environmental studies, which } \\
\text { support the identification and delimitation of Indigenous Land. }\end{array}$ \\
\hline Delimited & $\begin{array}{l}\text { Lands that had their studies approved by the Funai Presidency, with their conclusion published } \\
\text { in the Official Gazette of the Union and the State, and that are in the administrative contradictory } \\
\text { phase or under analysis by the Ministry of Justice, for a decision on the issuing of a Declaratory } \\
\text { Ordinance traditional Indigenous possession. }\end{array}$ \\
\hline
\end{tabular}


Table A1. Cont.

\begin{tabular}{ll}
\hline Stage & Description \\
\hline Declarated & $\begin{array}{l}\text { Lands that obtained the expedition of the Declaratory Ordinance by the Minister of Justice } \\
\text { and are authorized to be physically demarcated, with the materialization of the landmarks and } \\
\text { georeferencing. }\end{array}$ \\
\hline Homologated & $\begin{array}{l}\text { Lands that have their materialized and georeferenced limits, whose administrative demarcation } \\
\text { was approved by Presidential decree. }\end{array}$ \\
\hline Regularized & $\begin{array}{l}\text { Land that, after the homologation decree, was registered in a Notary's Office in the name of the } \\
\text { Union and in the Federal Heritage Secretariat. }\end{array}$ \\
\hline Forwarded with & $\begin{array}{l}\text { The Indigenous Reserve constitutes a differentiated category of Indigenous Land, mainly due } \\
\text { to the way it is acquired by the State and intended for the Indigenous population. In this way, } \\
\text { this category is out of the stages of the recognition process cited above. The Indigenous Reserves } \\
\text { are areas that are in the administrative process of acquisition by the Union (direct purchase, } \\
\text { expropriation or donation) intended for the possession and occupation of Indigenous peoples; } \\
\text { where they can live and obtain means of subsistence, with the right to enjoy and use natural } \\
\text { resources, guaranteeing the conditions for their physical and cultural reproduction. }\end{array}$ \\
\hline
\end{tabular}

Table A2. Final center of clusters.

\begin{tabular}{llccccccc}
\hline Where & Threat & Cluster 1 & Cluster 2 & Cluster 3 & Cluster 4 & Cluster 5 & Cluster 6 & Cluster 7 \\
\hline \multirow{5}{*}{ Indigenous Land } & deforestation & -0.35 & -0.26 & 0.29 & 0.31 & -1.98 & 0.58 & 0.03 \\
& degradation & -0.43 & 0.20 & -0.30 & 1.06 & -0.99 & 0.69 & -0.73 \\
& burned & -0.88 & 0.02 & -0.37 & 1.19 & 1.31 & 0.71 & -0.82 \\
& pasture & -0.96 & -0.06 & -0.22 & 1.06 & 0.43 & 0.93 & -0.83 \\
& crop & -0.34 & -0.21 & -0.32 & 3.11 & 0.35 & -0.23 & -0.34 \\
& mining & -0.02 & 3.17 & -0.32 & -0.32 & -0.32 & -0.29 & -0.32 \\
& roads & -0.86 & 0.19 & -0.36 & 1.16 & 1.15 & 0.68 & -0.83 \\
\hline \multirow{5}{*}{ Buffer Zone } & deforestation & -0.63 & 0.16 & 0.43 & 0.53 & -2.15 & 0.70 & -0.30 \\
& degradation & -0.59 & 0.27 & 0.12 & 1.04 & -1.33 & 0.64 & -1.01 \\
& burned & -1.12 & 0.06 & -0.04 & 1.03 & 1.18 & 0.81 & -1.15 \\
& pasture & -1.21 & 0.14 & 0.24 & 0.87 & 0.52 & 0.87 & -1.12 \\
& crop & -0.61 & -0.20 & -0.58 & 1.91 & 1.38 & 0.39 & -0.61 \\
& mining & -0.31 & 1.40 & -0.31 & -0.31 & -0.31 & -0.11 & 3.18 \\
& roads & -1.30 & 0.46 & 0.29 & 0.78 & 0.81 & 0.72 & -0.61 \\
\hline
\end{tabular}


Cluster 1

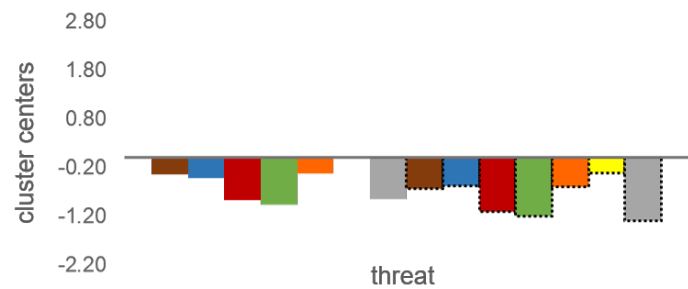

Cluster 3

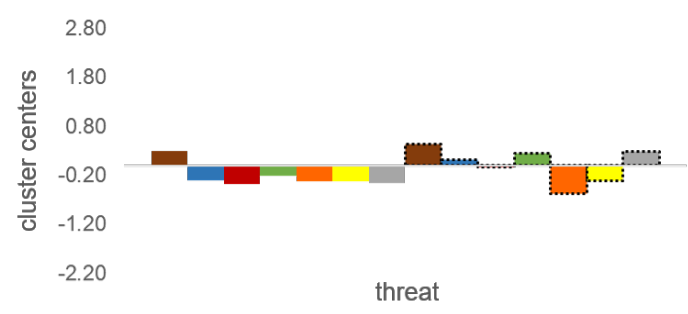

Cluster 5

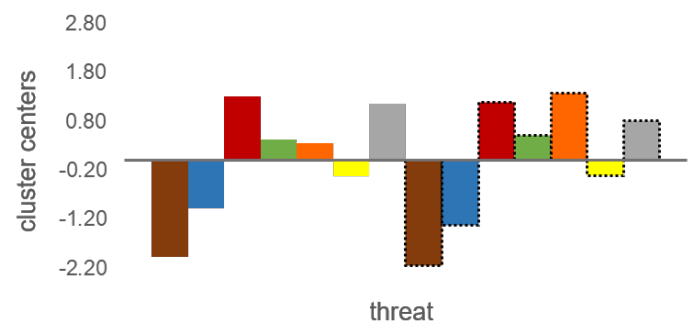

Cluster 7

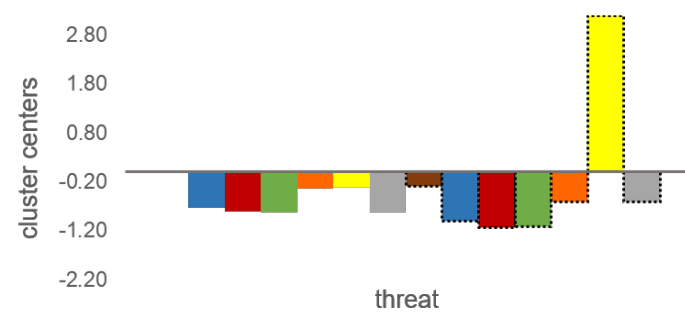

Cluster 2

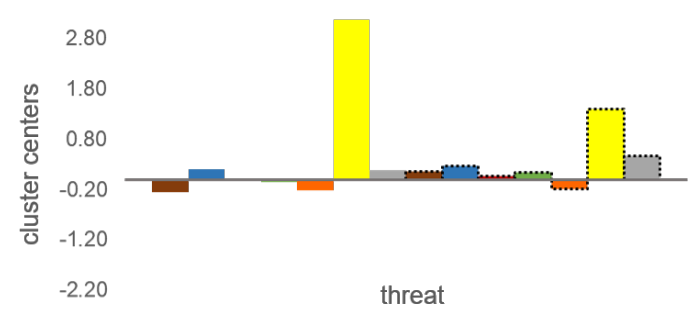

Cluster 4

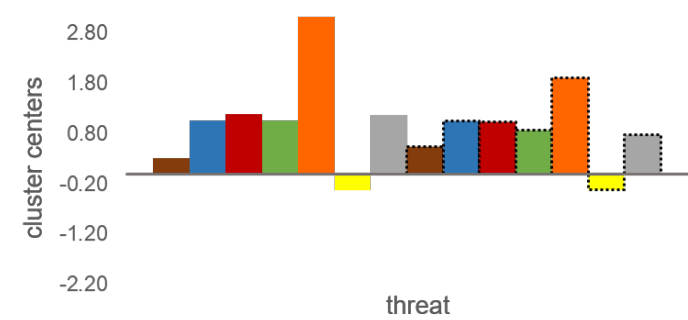

Cluster 6

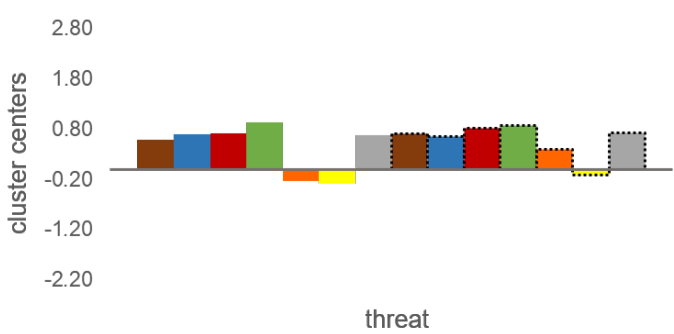

Figure A1. Bar charts of the clusters of Indigenous Lands. The values were plotted to represent the final cluster centers for each threat. Environmental threats within the Indigenous Land are plotted on the left, while threats in the Buffer Zone are plotted on the right with the dashed border. Threats in the buffer zone are identified by the abbreviation 'bf'. 'Defor' is an abbreviation for deforestation and 'degrad' for forest degradation. The central axis delimits the mean.

\section{References}

1. National Indian Foundation-FUNAI. National Indian Foundation. Available online: https://www.gov.br/funai/pt-br (accessed on 20 November 2019).

2. Brazilian Federal Constitution. Article 231/1988. 1988. Available online: http://www.planalto.gov.br/ccivil_03/constituicao/ constituicao.htm (accessed on 12 April 2020).

3. Brazilian Legislative Power. Law 6.001/1973. 1973. Available online: http://www.planalto.gov.br/ccivil_03/leis/16001.htm (accessed on 12 April 2020).

4. Brazilian Executive Power. Law 5.173/1966. 1966. Available online: http://www.planalto.gov.br/ccivil_03/leis/L5173.htm (accessed on 13 May 2020).

5. Socioenvironmental Institute-ISA. Terras Indígenas no Brasil. 2019. Available online: https://terrasindigenas.org.br/ (accessed on 20 April 2019).

6. Walker, W.; Baccini, A.; Schwartzman, S.; Ríos, S.; Oliveira-Miranda, M.A.; Augusto, C.; Ruiz, M.R.; Arrasco, C.S.; Ricardo, B.; Smith, R.; et al. Forest Carbon in Amazonia: The Unrecognized Contribution of Indigenous Territories and Protected Natural Areas. Carbon Manag. 2014, 5, 479-485. [CrossRef] 
7. Ricketts, T.H.; Soares-Filho, B.; da Fonseca, G.A.; Nepstad, D.; Pfaff, A.; Petsonk, A.; Anderson, A.; Boucher, D.; Cattaneo, A.; Conte, M.; et al. Indigenous lands, protected areas, and slowing climate change. PLoS Biol. 2010, 8, e1000331. [CrossRef]

8. Fernández-Llamazares, Á.; Terraube, J.; Gavin, M.C.; Pyhälä, A.; Siani, S.M.; Cabeza, M.; Brondizio, E.S. Reframing the wilderness concept can bolster collaborative conservation. Trends Ecol. Evol. 2020, 35, 750-753. [CrossRef]

9. Begotti, R.A.; Peres, C.A. Rapidly escalating threats to the biodiversity and ethnocultural capital of Brazilian Indigenous Lands. Land Use Policy 2020, 96, 104694. [CrossRef]

10. Nepstad, D.; Schwartzman, S.; Bamberger, B.; Santilli, M.; Ray, D.; Schlesinger, P.; Lefebvre, P.; Alencar, A.; Prinz, E.; Fiske, G.; et al. Inhibition of Amazon deforestation and fire by parks and indigenous lands. Conserv. Biol. 2006, 20, 65-73. [CrossRef]

11. Soares-Filho, B.; Moutinho, P.; Nepstad, D.; Anderson, A.; Rodrigues, H.; Garcia, R.; Dietzsch, L.; Merry, F.; Bowman, M.; Hissa, L.; et al. Role of Brazilian Amazon Protected Areas in Climate Change Mitigation. Proc. Natl. Acad. Sci. USA 2010, 107, 10821-10826. [CrossRef]

12. Nelson, A.; Chomitz, K.M. Effectiveness of strict vs. multiple use protected areas in reducing tropical forest fires: A global analysis using matching methods. PLoS ONE 2011, 6, e22722. [CrossRef] [PubMed]

13. Nepstad, D.C.; Stickler, C.M.; Filho, B.S.; Merry, F. Interactions among Amazon land use, forests and climate: Prospects for a near-term forest tipping point. Philos. Trans. R. Soc. Biol. Sci. 2008, 363, 1737-1746. [CrossRef] [PubMed]

14. Carneiro Filho, A.; Souza, O.B. Atlas de Pressões e Ameaças às Terras Indígenas na Amazônia Brasileira. 2009. Available online: https: //www.socioambiental.org/pt-br/o-isa/publicacoes/atlas-de-pressoes-e-ameacas-as-terras-indigenas-na-amazonia-brasileira (accessed on 20 August 2018).

15. Ricardo, B.; Ricardo, F. Povos Indígenas no Brasil: 2006/2010; Instituto Socioambiental: São Paulo, Brasil, 2011.

16. Le Tourneau, F.M. The Sustainability Challenges of Indigenous Territories in Brazil's Amazonia. Curr. Opin. Environ. Sustain. 2015, 14, 213-220. [CrossRef]

17. Socioenvironmental Institute-ISA. Terras+. 2019. Available online: http://terrasmais.eco.br (accessed on 30 April 2019).

18. National Institute for Space Research-INPE. Amazon Deforestation Monitoring Project (PRODES). 2020. Available online: http:/ / terrabrasilis.dpi.inpe.br/downloads / (accessed on 30 April 2020).

19. National Institute for Space Research-INPE. Portal for Monitoring Fires. 2020. Available online: http://http:/ /queimadas.dgi. inpe.br/queimadas/bdqueimadas (accessed on 15 August 2019).

20. Ferrante, L.; Gomes, M.; Fearnside, P.M. Amazonian indigenous peoples are threatened by Brazil's Highway BR-319. Land Use Policy 2020, 94, 104548. [CrossRef]

21. Sonter, L.J.; Herrera, D.; Barrett, D.J.; Galford, G.L.; Moran, C.J.; Soares-Filho, B.S. Mining Drives Extensive Deforestation in the Brazilian Amazon. Nat. Commun. 2017, 8, 1-7. [CrossRef] [PubMed]

22. Rorato, A.C.; Camara, G.; Escada, M.I.S.; Picoli, M.C.A.; Moreira, T.; Verstegen, J.A. Brazilian Amazon indigenous peoples threatened by mining bill. Environ. Res. Lett. 2020, 15, 1040a3. [CrossRef]

23. Siqueira-Gay, J.; Soares-Filho, B.; Sanchez, L.E.; Oviedo, A.; Sonter, L.J. Proposed Legislation to Mine Brazil's Indigenous Lands Will Threaten Amazon Forests and Their Valuable Ecosystem Services. One Earth 2020, 3, 356-362. [CrossRef]

24. Nepstad, D.C.; Stickler, C.M.; Almeida, O.T. Globalization of the Amazon soy and beef industries: Opportunities for conservation. Conserv. Biol. 2006, 20, 1595-1603. [CrossRef] [PubMed]

25. Gibbs, H.K.; Ruesch, A.S.; Achard, F.; Clayton, M.K.; Holmgren, P.; Ramankutty, N.; Foley, J.A. Tropical Forests Were the Primary Sources of New Agricultural Land in the 1980s and 1990s. Proc. Natl. Acad. Sci. USA 2010, 107, 16732-16737. [CrossRef] [PubMed]

26. Laurance, W.F.; Clements, G.R.; Sloan, S.; O'connell, C.S.; Mueller, N.D.; Goosem, M.; Venter, O.; Edwards, D.P.; Phalan, B.; Balmford, A.; et al. A global strategy for road building. Nature 2014, 513, 229-232. [CrossRef]

27. Costa, F.d.A. Land market and technological trajectories in Amazonia. Economia e Sociedade 2012, 21, 245-273. [CrossRef]

28. Camara, G.; Soterroni, A.; Ramos, F.; Carvalho, A.; Andrade, P.; Cartaxo, R.; Mosnier, A.; Mant, R.; Buurman, M.; Pena, M.; et al. Modelling Land Use Change in Brazil: 2000-2050; Technical Report; INPE; IPEA: Sao Jose dos Campos, Brazil; IIASA: Laxenburg, Austria; UNEP-WCMC: Cambridge, UK, 2015.

29. de Araujo Lima Constantino, P. Deforestation and hunting effects on wildlife across Amazonian indigenous lands. Ecol. Soc. 2016, 21. [CrossRef]

30. Indigenist Missionary Council—CIMI. Violence against Indigenous Peoples in Brazil (Data for 2018). 2019. Available online: https:/ / cimi.org.br/observatorio-da-violencia/edicoes-anteriores/ (accessed on 20 January 2020).

31. Indigenist Missionary Council—CIMI. Violence against Indigenous Peoples in Brazil (Data for 2019). 2019. Available online: https:/ / cimi.org.br/observatorio-da-violencia/edicoes-anteriores/ (accessed on 10 December 2020).

32. Abessa, D.; Famá, A.; Buruaem, L. The Systematic Dismantling of Brazilian Environmental Laws Risks Losses on All Fronts. Nat. Ecol. Evol. 2019, 3, 510-511. [CrossRef] [PubMed]

33. Pereira, E.J.d.A.L.; Ferreira, P.J.S.; de Santana Ribeiro, L.C.; Carvalho, T.S.; de Barros Pereira, H.B. Policy in Brazil (2016-2019) threaten conservation of the Amazon rainforest. Environ. Sci. Policy 2019, 100, 8-12. [CrossRef]

34. Brazilian Executive Power. Bill 191/2020. 2020. Available online: https://www.camara.leg.br/proposicoesWeb/ fichadetramitacao?idProposicao=2236765 (accessed on 10 August 2020).

35. Artaxo, P. Working together for Amazonia. Science 2019, 363, 323. [CrossRef] [PubMed]

36. Escobar, H. Scientists, environmentalists brace for Brazil's right turn. Science 2018, 362, 273-274. [CrossRef]

37. Begotti, R.A.; Peres, C.A. Brazil's Indigenous Lands under Threat. Science 2019, 363, 592. [CrossRef] 
38. Human Rights Watch. Rainforest Mafias: How Violence and Impunity Fuel Deforestation in Brazil's Amazon. 2019. Available online: https:/ / www.hrw.org/report/2019/09/17/rainforest-mafias/how-violence-and-impunity-fuel-deforestationbrazils-amazon\#_ftn37 (accessed on 25 June 2020).

39. World Gold Council. Gold Price \& Gold Market Data and Research. 2020. Available online: https://www.gold.org/goldhub/ data/gold-prices (accessed on 29 July 2020).

40. DeFries, R.; Hansen, A.; Newton, A.C.; Hansen, M.C. Increasing isolation of protected areas in tropical forests over the past twenty years. Ecol. Appl. 2005, 15, 19-26. [CrossRef]

41. Joppa, L.N.; Loarie, S.R.; Pimm, S.L. On the protection of "protected areas". Proc. Natl. Acad. Sci. USA 2008, 105, 6673-6678. [CrossRef]

42. Cabral, A.I.; Saito, C.; Pereira, H.; Laques, A.E. Deforestation pattern dynamics in protected areas of the Brazilian Legal Amazon using remote sensing data. Appl. Geogr. 2018, 100, 101-115. [CrossRef]

43. Nogueira, E.M.; Yanai, A.M.; de Vasconcelos, S.S.; de Alencastro Graça, P.M.L.; Fearnside, P.M. Carbon stocks and losses to deforestation in protected areas in Brazilian Amazonia. Reg. Environ. Chang. 2018, 18, 261-270. [CrossRef]

44. Lapola, D.M.; Silva, J.M.C.d.; Braga, D.R.; Carpigiani, L.; Ogawa, F.; Torres, R.R.; Barbosa, L.C.; Ometto, J.P.; Joly, C.A. A climatechange vulnerability and adaptation assessment for Brazil's protected areas. Conserv. Biol. 2020, 34, 427-437. [CrossRef] [PubMed]

45. Wolters, V.; Silver, W.L.; Bignell, D.E.; Coleman, D.C.; Lavelle, P.; Van Der Putten, W.H.; De Ruiter, P.; Rusek, J.; Wall, D.H.; Wardle, D.A.; et al. Effects of Global Changes on Above-and Belowground Biodiversity in Terrestrial Ecosystems: Implications for Ecosystem Functioning: We identify the basic types of interaction between vascular plants and soil biota; describe the sensitivity of each type to changes in species composition; and, within this framework, evaluate the potential consequences of global change drivers on ecosystem processes. Bioscience 2000, 50, 1089-1098. [CrossRef]

46. Morris, R.J. Anthropogenic impacts on tropical forest biodiversity: A network structure and ecosystem functioning perspective. Philos. Trans. R. Soc. Biol. Sci. 2010, 365, 3709-3718. [CrossRef]

47. Diniz, C.G.; Souza, A.A.d.A.; Santos, D.C.; Dias, M.C.; da Luz, N.C.; de Moraes, D.R.V.; Maia, J.S.A.; Gomes, A.R.; Narvaes, I.d.S.; Valeriano, D.M.; et al. DETER-B: The New Amazon Near Real-Time Deforestation Detection System. IEEE J. Sel. Top. Appl. Earth Obs. Remote. Sens. 2015, 8, 3619-3628. [CrossRef]

48. National Institute for Space Research-INPE. Monitoramento da Cobertura Florestal da Amazônia por SatéLites. Sistemas PRODES, DETER, DEGRAD e Queimadas; Technical Report; National Institute for Space Research-INPE: São José dos Campos, Brazil, 2008.

49. Barlow, J.; Berenguer, E.; Carmenta, R.; França, F. Clarifying Amazonia's burning crisis. Glob. Chang. Biol. 2020, 26, 319-321. [CrossRef] [PubMed]

50. Lacerda, F. Prevenção e Monitoramento de Incêndios Florestais em terras indíGenas: Programa de Capacitação em Proteção Territorial. 2013. Available online: http://www.funai.gov.br/arquivos/conteudo/cgmt/pdf/Prevencao_e_Monitoramento_de_ Incendios_Florestais_em_TIs.pdf (accessed on 12 September 2020).

51. Aragão, L.E.; Anderson, L.O.; Fonseca, M.G.; Rosan, T.M.; Vedovato, L.B.; Wagner, F.H.; Silva, C.V.; Junior, C.H.S.; Arai, E.; Aguiar, A.P.; et al. 21st Century drought-related fires counteract the decline of Amazon deforestation carbon emissions. Nat. Commun. 2018, 9, 1-12. [CrossRef]

52. Cochrane, M.A.; Schulze, M.D. Fire as a Recurrent Event in Tropical Forests of the Eastern Amazon: Effects on Forest Structure, Biomass, and Species Composition 1. Biotropica 1999, 31, 2-16. [CrossRef]

53. Ribeiro, M.F.; Barba, M.D. Abandonadas pela Funai, $60 \%$ das terras indígenas são devastadas por mais de 100 mil focos de incêndio. Available online: https:/ / reporterbrasil.org.br/2020/11/abandonadas-pela-funai-60-das-terras-indigenas-saodevastadas-100-mil-focos-de-incendio /?utm_campaign=shareaholic\&utm_medium=twitter\&utm_source=socialnetwork (accessed on 20 November 2020).

54. Angelo, M. Enquanto Brasil Queima, Brigadas IndíGenas de Combate ao fogo Encaram Futuro Incerto. 2020. Available online: https:/ / brasil.mongabay.com/2020/10/enquanto-brasil-queima-brigadas-indigenas-de-combate-ao-fogo-encaram-futuroincerto/ (accessed on 15 November 2020).

55. Lambin, E.F.; Meyfroidt, P. Global Land Use Change, Economic Globalization, and the Looming Land Scarcity. Proc. Natl. Acad. Sci. USA 2011, 108, 3465-3472. [CrossRef] [PubMed]

56. Turner, B.L.; Lambin, E.F.; Reenberg, A. The emergence of land change science for global environmental change and sustainability. Proc. Natl. Acad. Sci. USA 2007, 104, 20666-20671. [CrossRef]

57. Harper, K.A.; Macdonald, S.E.; Burton, P.J.; Chen, J.; Brosofske, K.D.; Saunders, S.C.; Euskirchen, E.S.; Roberts, D.; Jaiteh, M.S.; Esseen, P.A. Edge influence on forest structure and composition in fragmented landscapes. Conserv. Biol. 2005, 19, 768-782. [CrossRef]

58. Escada, M.I.S.; Alves, D.S. Mudanças de uso e Cobertura do solo na Amazônia: Impactos sócio-Ambientais na Ocupação de Regiões de Fronteira Agrícola; Technical Report; National Institute for Space Research-INPE: São José dos Campos, Brasil 2001.

59. Alves, D.S. Space-time dynamics of deforestation in Brazilian Amazonia. Int. J. Remote. Sens. 2002, 23, 2903-2908. [CrossRef]

60. Soares-Filho, B.; Alencar, A.; Nepstad, D.; Cerqueira, G.; Vera Diaz, M.d.C.; Rivero, S.; Solórzano, L.; Voll, E. Simulating the response of land-cover changes to road paving and governance along a major Amazon highway: The Santarém-Cuiabá corridor. Glob. Chang. Biol. 2004, 10, 745-764. [CrossRef] 
61. Soares-Filho, B.S.; Nepstad, D.C.; Curran, L.M.; Cerqueira, G.C.; Garcia, R.A.; Ramos, C.A.; Voll, E.; McDonald, A.; Lefebvre, P.; Schlesinger, P. Modelling conservation in the Amazon basin. Nature 2006, 440, 520-523. [CrossRef]

62. Hilson, G. An Overview of Land Use Conflicts in Mining Communities. Land Use Policy 2002, 19, 65-73. [CrossRef]

63. Horowitz, L.S.; Keeling, A.; Lévesque, F.; Rodon, T.; Schott, S.; Thériault, S. Indigenous Peoples' Relationships to Large-Scale Mining in Post/Colonial Contexts: Toward Multidisciplinary Comparative Perspectives. Extr. Ind. Soc. 2018, 5, $404-414$. [CrossRef]

64. Vega, C.M.; Orellana, J.D.Y.; Oliveira, M.W.; Hacon, S.S.; Basta, P.C. Human Mercury Exposure in Yanomami Indigenous Villages from the Brazilian Amazon. Int. J. Environ. Res. Public Health 2018, 15, 1051. [CrossRef]

65. Oiveira, V. Brazil: Prospectors Murder 2 Yanomamis over Land. Available online: http://www.hlrn.org/news.php?id=p3FraQ= =\#.XySNnyhKjIU (accessed on 31 July 2020).

66. Phillips, D. Amazon Gold Miners Invade Indigenous Village in Brazil after Its Leader Is Killed. Available online: https:// www.theguardian.com/world/2019/jul/28/amazon-gold-miners-invade-indigenous-village-brazil-leader-killed (accessed on 31 July 2020).

67. Global Witness. DEFENDING TOMORROW: The Climate Crisis and Threats against Land and Environmental Defenders. Available online: https:/ / www.globalwitness.org/en/campaigns/environmental-activists/defending-tomorrow/ (accessed on 29 July 2020).

68. Ferreira, J.; Aragao, L.; Barlow, J.; Barreto, P.; Berenguer, E.; Bustamante, M.; Gardner, T.A.; Lees, A.C.; Lima, A.; Louzada, J.; et al. Brazil's Environmental Leadership at Risk. Science 2014, 346, 706-707. [CrossRef]

69. Alvarez-Berrios, N.L.; Aide, T.M. Global Demand for Gold Is Another Threat for Tropical Forests. Environ. Res. Lett. 2015, 10, 014006. [CrossRef]

70. National Institute for Space Research-INPE. Near Real-Time Deforestation Detection System (DETER). 2020. Available online: http: / / terrabrasilis.dpi.inpe.br/downloads / (accessed on 30 April 2020).

71. National Indian Foundation-FUNAI. Terras Indígenas/Terras Indígenas em Estudos. 2019. Available online: http://www. funai.gov.br/index.php/shape (accessed on 20 November 2019).

72. National Indian Foundation-FUNAI. Indigenous Lands/Indigenous Lands in Studies. 2019. Available online: http://www funai.gov.br/index.php/shape (accessed on 20 November 2019).

73. Ministério do Meio Ambiente-MMA. Portaria Interministerial 60/2015. 2015. Available online: http://www.lex.com.br/legis_ 26632223_portaria_interministerial_n_60_de_24_de_marco_de_2015.aspx (accessed on 12 April 2020).

74. Giglio, L.; Boschetti, L.; Roy, D.P.; Humber, M.L.; Justice, C.O. The Collection 6 MODIS burned area mapping algorithm and product. Remote. Sens. Environ. 2018, 217, 72-85. [CrossRef]

75. Camara, G.; Simoes, R.; Picoli, M.; Andrade, P.R.; Rorato, A.; Santos, L.; Maciel, A.; Sanches, I.; Coutinho, A.; Esquerdo, J.; et al. Land Use and Land Cover Maps for Amazon Biome in Brazil for 2001-2019 Derived from MODIS Time Series. Sci. Data 2020, 7, 34. [CrossRef]

76. Rede Amazônica de Informação Socioambiental Georreferenciada-RAISG. Dados Cartográficos. Available online: https: //www.amazoniasocioambiental.org/es/mapas/ (accessed on 20 November 2019).

77. Javadi, S.; Hashemy, S.; Mohammadi, K.; Howard, K.; Neshat, A. Classification of aquifer vulnerability using K-means cluster analysis. J. Hydrol. 2017, 549, 27-37. [CrossRef]

78. Fernandez, P.; Mourato, S.; Moreira, M.; Pereira, L. A new approach for computing a flood vulnerability index using cluster analysis. Phys. Chem. Earth Parts A/B/C 2016, 94, 47-55. [CrossRef]

79. Mohamad, I.; Usman, D. Standardization and Its Effects on K-Means Clustering Algorithm. Res. J. Appl. Sci. Eng. Technol. 2013, 6, 3299-3303. [CrossRef]

80. Maroco, J. Análise estatística: Com Utilização do SPSS; Edições Sílabo: Lisboa, Portugal, 2007.

81. Han, J.; Pei, J.; Kamber, M. Data Mining: Concepts and Techniques; Elsevier: Amsterdam, The Netherlands, 2011.

82. Calinski, T.; Harabasz, J. A dendrite method for cluster analysis. Commun. Stat. Theory Methods 1974, 3, 1-27. [CrossRef]

83. R Core Team. R: A Language and Environment for Statistical Computing; R Foundation for Statistical Computing: Vienna, Austria, 2014.

84. ESRI. ArcGIS Desktop 10.4; Environmental Systems Research Institute (ESRI): Redlands, CA, USA, 2016.

85. QGIS Development Team. QGIS Geographic Information System; Open Source Geospatial Foundation: Brazil, 2009. Available online: https:/ / qgis.org/en/site/ (accessed on 10 December 2020).

86. IBM Corp. IBM SPSS Statistics for Windows; IBM Corp: Armonk, NY, USA, 2013.

87. Becker, B.K. Geopolitics of the Amazon. Area Dev. Policy 2016, 1, 15-29. [CrossRef]

88. Nolte, C.; Agrawal, A.; Silvius, K.M.; Soares-Filho, B. Governance Regime and Location Influence Avoided Deforestation Success of Protected Areas in the Brazilian Amazonia. Proc. Natl. Acad. Sci. USA 2013, 110, 4956-4961. [CrossRef] [PubMed]

89. Aguiar, A.; Camara, G.; Escada, I. Spatial Statistical Analysis of Land-Use Determinants in the Brazilian Amazonia: Exploring Intra-Regional Heterogeneity. Ecol. Model. 2007, 209, 169-188. [CrossRef]

90. Raisg. Amazonía bajo Presión, 2020. Available online: https://www.amazoniasocioambiental.org/pt-br/publicacao/amazoniasob-pressao-2020/ (accessed on 10 December 2020).

91. Schielein, J.; Börner, J. Recent transformations of land-use and land-cover dynamics across different deforestation frontiers in the Brazilian Amazon. Land Use Policy 2018, 76, 81-94. [CrossRef] 
92. Brazilian Institute of Geography and Statistics-IBGE. Municipal Agricultural Production. 2020. Available online: https: / / sidra.ibge.gov.br/pesquisa/pam/tabelas (accessed on 1 November 2020).

93. Brazilian Institute of Geography and Statistics-IBGE. Municipal Livestock Research. Available online: https://sidra.ibge.gov. $\mathrm{br} /$ pesquisa/ppm/tabelas (accessed on 1 November 2020).

94. Arima, E.Y.; Barreto, P.; Araujo, E.; Soares-Filho, B. Public Policies Can Reduce Tropical Deforestation: Lessons and Challenges from Brazil. Land Use Policy 2014, 41, 465-473. [CrossRef]

95. Trebat, T.J.; Nora, L.; Caldwell, I. Threats to the Brazilian Environment and Environmental Policy. Available online: https://globalcenters.columbia.edu/sites /default/files/content/Workshop_Report_Threats\%20to\%20the\%20Brazilian \%20 Environment.pdf (accessed on 5 November 2020).

96. Junior, C.H.S.; Celentano, D.; Rousseau, G.X.; de Moura, E.G.; van Deursen Varga, I.; Martinez, C.; Martins, M.B. Amazon forest on the edge of collapse in the Maranhão State, Brazil. Land Use Policy 2020, 97, 104806. [CrossRef]

97. Editorial of O Estado de S. Paulo. O Ibama Sem Dentes. Available online: https://opiniao.estadao.com.br/noticias/notas-einformacoes, o-ibama-sem-dentes,70003530150 (accessed on 29 November 2020).

98. Dantas, C. Apenas 3 de Quase mil autuações aplicadas pelo Ibama por Desmate na Amazônia em 2020 Foram Quitadas. 2020. Available online: https://g1.globo.com/natureza/amazonia/noticia/2020/10/31/apenas-3-de-quase-mil-autuacoes-aplicadaspelo-ibama-por-desmate-na-amazonia-foram-quitadas-em-2020.ghtml (accessed on 31 October 2020).

99. Camargos, D. In an Offensive against Indigenous People in Pará, illegal gold Miners Move Billionaire Market. 2019. Available online: https:/ / reporterbrasil.org.br/2019/11/em-ofensiva-contra-indigenas-no-para-garimpeiros-ilegais-movimentammercado-bilionario/ (accessed on 2 February 2020).

100. Brancalion, P.H.; de Almeida, D.R.; Vidal, E.; Molin, P.G.; Sontag, V.E.; Souza, S.E.; Schulze, M.D. Fake legal logging in the Brazilian Amazon. Sci. Adv. 2018, 4, eaat1192. [CrossRef]

101. Brazilian Institute of the Environment and Renewable Natural Resources-IBAMA. National Center for the Prevention and Fighting of Forest Fires (Prevfogo). Available online: https:/ /www.ibama.gov.br/prevfogo (accessed on 20 November 2020).

102. Ferrante, L.; Fearnside, P.M. Brazil threatens Indigenous lands. Science 2020, 368, 481-482. [PubMed]

103. Eloy, L.; A. Bilbao, B.; Mistry, J.; Schmidt, I.B. From fire suppression to fire management: Advances and resistances to changes in fire policy in the savannas of Brazil and Venezuela. Geogr. J. 2019, 185, 10-22. [CrossRef]

104. Verdélio, A. Força Nacional permanecerá por mais 90 dias em terra indígena no Pará. 2020. Available online: https: / /agenciabrasil.ebc.com.br/geral/noticia/2020-07/forca-nacional-permanecera-por-mais-90-dias-em-terra-indigena-no-para (accessed on 21 August 2020).

105. Phillips, D. 'Like a Bomb Going off': Why Brazil's Largest Reserve Is Facing Destruction. https://www.theguardian. com/environment/2020/jan/13/like-a-bomb-going-off-why-brazils-largest-reserve-is-facing-destruction-aoe (accessed on 2 February 2020).

106. Socioenvironmental Institute-ISA. The Impact of the Pandemic on the Yanomami Indigenous Land (O Impacto da Pandemia na Terra Indígena Yanomami - In Portuguese); Technical Report; Instituto Socioambiental: São Paulo, Brazil, 2020.

107. Walker, R.T.; Simmons, C.; Arima, E.; Galvan-Miyoshi, Y.; Antunes, A.; Waylen, M.; Irigaray, M. Avoiding Amazonian catastrophes: Prospects for conservation in the 21st century. One Earth 2019, 1, 202-215. [CrossRef]

108. Athayde, S. Introduction: Indigenous peoples, dams and resistance. Tipiti J. Soc. Anthropol. Lowl. S. Am. 2014, $12,80-92$.

109. Walker, R.; Simmons, C. Endangered Amazon: An indigenous tribe fights back against hydropower development in the Tapajós Valley. Environ. Sci. Policy Sustain. Dev. 2018, 60, 4-15. [CrossRef]

110. Maconachie, R. Diamonds, governance and 'local'development in post-conflict Sierra Leone: Lessons for artisanal and small-scale mining in sub-Saharan Africa? Resour. Policy 2009, 34, 71-79. [CrossRef]

111. Garnett, S.T.; Burgess, N.D.; Fa, J.E.; Fernández-Llamazares, Á.; Molnár, Z.; Robinson, C.J.; Watson, J.E.; Zander, K.K.; Austin, B.; Brondizio, E.S.; et al. A spatial overview of the global importance of Indigenous lands for conservation. Nat. Sustain. 2018, 1, 369. [CrossRef]

112. Baragwanath, K.; Bayi, E. Collective property rights reduce deforestation in the Brazilian Amazon. Proc. Natl. Acad. Sci. USA 2020, 117, 20495-20502. [CrossRef] [PubMed]

113. Brazilian Executive Power. Decree 7.747/2012. 2012. Available online: http://www.planalto.gov.br/ccivil_03/_ato2011-2014/2 012/decreto/d7747.htm (accessed on 20 December 2020).

114. SOMAI. Sistema de OBSERVAÇÃO E Monitoramento da AMAZÔNIA indÍgena. 2020. Available online: http://www.somai.org br/plataforma/ (accessed on 20 December 2020).

115. National Indian Foundation. Normative Instruction 9/2020. 2020. Available online: https://www.in.gov.br/web/dou/-/ instrucao-normativa-n-9-de-16-de-abril-de-2020-253343033 (accessed on 20 February 2021).

116. de Gusmão, H.N.B.; Baldassa, T.T. Indigenous Lands overlaid by Rural Registries in Brazil. 2020. Available online: https: / / deolhonosruralistas.com.br/overlap-indigenouslands / (accessed on 20 February 2021).

117. Siqueira-Gay, J.; Sonter, L.J.; Sánchez, L.E. Exploring potential impacts of mining on forest loss and fragmentation within a biodiverse region of Brazil's northeastern Amazon. Resour. Policy 2020, 67, 101662. [CrossRef] 